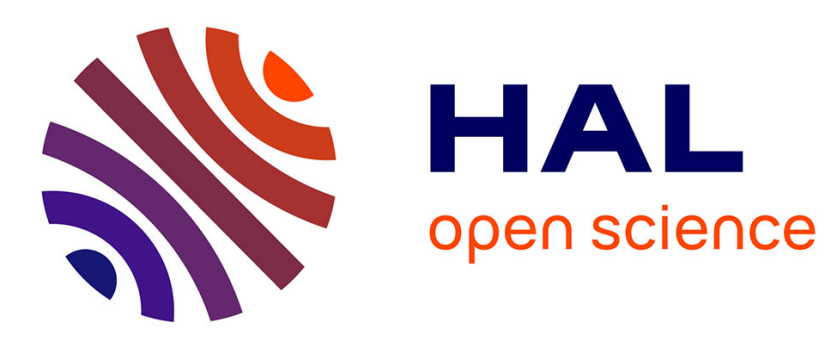

\title{
The Syntheses and Properties of 1,2-Epoxyalkylphosphonates
}

Bogdan Iorga, Frédéric Eymery, Philippe Savignac

\section{To cite this version:}

Bogdan Iorga, Frédéric Eymery, Philippe Savignac. The Syntheses and Properties of 1,2Epoxyalkylphosphonates. Synthesis: Journal of Synthetic Organic Chemistry, 1999, 1999 (02), pp.207224. 10.1055/s-1999-3378. hal-03161383

\section{HAL Id: hal-03161383 https://hal.science/hal-03161383}

Submitted on 10 Mar 2021

HAL is a multi-disciplinary open access archive for the deposit and dissemination of scientific research documents, whether they are published or not. The documents may come from teaching and research institutions in France or abroad, or from public or private research centers.
L'archive ouverte pluridisciplinaire HAL, est destinée au dépôt et à la diffusion de documents scientifiques de niveau recherche, publiés ou non, émanant des établissements d'enseignement et de recherche français ou étrangers, des laboratoires publics ou privés. 


\title{
The Syntheses and Properties of 1,2-Epoxyalkylphosphonates
}

\author{
Bogdan Iorga, Frédéric Eymery and Philippe Savignac
}

Laboratoire Hétéroéléments et Coordination, UMR CNRS 7653, DCPH, Ecole Polytechnique 91128 Palaiseau Cedex, France.*

\begin{abstract}
The present review article deals with the methods of preparation of dialkyl 1,2epoxyalkylphosphonates as well as synthetically useful reactions of this class of compounds. Four main routes to 1,2-epoxyalkylphosphonates are described, in which new developments adapted to each processes are given, including the choice of the leaving group, new cyclisation methods and stereocontrol induction. Thermal and acid catalyzed rearrangements are also covered, and the use of the oxirane ring by nucleophilic opening is highlighted. Particular emphasis is placed on the synthetic approaches to antibiotic fosfomycin.
\end{abstract}

Key words: Darzens reaction, halohydrins, haloketones, fosfomycin, opening and rearrangement reactions.

\section{Introduction \\ 2. Preparations}

\subsection{The Darzens reaction}

2.2. The reaction of sodium dialkylphosphite with $\alpha$-haloketones

2.3. The reaction of dialkyl halohydrinphosphonates and related structures with bases

2.4. The direct epoxidation of $\alpha, \beta$-unsaturated phosphonates

3. Preparations of fosfomycin

4. Rearrangements of 1,2-epoxyalkylphosphonates

5. Reactions of 1,2-epoxyalkylphosphonates

6. Conclusion

* Tel. (+33) 01693345 79. Fax. (+33) 0169333990.

E-mail: dcph@poly.polytechnique.fr 


\section{Introduction}

The discovery of antibiotic fosfomycin ${ }^{1}[(-)(1 R, 2 S)-(Z)-1,2$-epoxypropylphosphonic acid] in 1969 has generated a regular interest in the chemistry of 1,2-epoxyalkylphosphonates and gave rise to a large number of synthetic preparations. It has also given to 1,2epoxyalkylphosphonates and derivatives a biochemical significance. As a consequence of this discovery, a lot of research has resulted in the extensive development of methodologies in order to prepare analogs of fosfomycin and to diversify the syntheses. These techniques have largely contributed to extend the synthetic utility of the epoxyphosphonate function and have greatly diversified the reactions available for the construction of the epoxide ring. As synthetic intermediates, these compounds owe their interest to the presence of the epoxide ring, which participates as an electrophilic site and governs their chemical reactivity. The purpose of this review is to provide a general overview of the synthetic reactions, which have been realized in the epoxyphosphonate field and to help focus attention on these valuable derivatives. In this paper, the various methods of preparation of 1,2-epoxyalkylphosphonates, with an emphasis on the syntheses of fosfomycin, and the types of reactions they undergo are summarized.

\section{Preparations}

Several methods of synthesis of dialkyl 1,2-epoxyalkylphosphonates are known, they may be classified into four main categories of reactions including (a) the Darzens reaction of dialkyl chloromethylphosphonates with carbonyl compounds, (b) the reaction of sodium dialkylphosphites with $\alpha$-haloketones, (c) the reaction of dialkyl halohydrinphosphonates with bases, and (d) the oxidation of 1,2-unsaturated phosphonates with a peroxide. These procedures, which usually involve a one-step operation, allow the coverage of a large variety of dialkyl 1,2-epoxyalkylphosphonates.

\subsection{The Darzens reaction}

The Darzens synthesis of glycidic esters by the condensation of carbonyl compounds with $\alpha$-haloesters ${ }^{2}$ is an important and useful method, which has been extended in phosphorus chemistry. Unquestionably, the most general and perhaps most widely employed method for the synthesis of dialkyl 1,2-epoxyalkylphosphonates involves the reaction of dialkyl chloromethylphosphonates $\mathbf{1}$ with carbonyl compounds. The synthetically useful dialkyl chloromethylphosphonates $\mathbf{1}$ were readily obtained by standard alcoholysis under anhydrous 
conditions of the chloromethylphosphonyl dichloride. ${ }^{3}$ The latter was obtained in up to $67 \%$ yield from phosphorus trichloride and paraformaldehyde at $250^{\circ} \mathrm{C} .{ }^{4}$ Several variations on the preparation of dialkyl 1,2-epoxyalkylphosphonates $\mathbf{3}$ from dialkyl chloromethylphosphonates 1 and different carbonyl partners have been reported. The conditions of generating the $\alpha$ metallated dialkyl chloromethylphosphonates were found to be critical due to their notorious instability. With alkoxide bases, the addition of sodium ethoxide or potassium $t$-butoxide to an equimolecular amount of dialkyl chloromethylphosphonate and carbonyl compound (aromatic aldehydes or ketones) in diethyl ether or $t$-butyl alcohol at temperatures varying between $-10^{\circ} \mathrm{C}$ and $+10^{\circ} \mathrm{C}$ leads to dialkyl 1,2-epoxyalkylphosphonates in low to good yields $(10-68 \%) .5$ Best yields were obtained when the dialkyl chloromethylphosphonates 1 were metallated by treatment with $n$-BuLi in THF at low temperature. ${ }^{6}$ The resulting carbanions 2 undergo facile addition with carbonyl compounds to give the almost immediate formation of chlorohydrins, which on warming conduce quantitatively to dialkyl 1,2epoxyalkylphosphonates 3 without trace of side products (Scheme 1). These conditions were found to be preferable for preparing dialkyl 1,2-epoxyalkylphosphonates 3 in pure form and in good to excellent yield (50-90\%). This method appears to be applicable to a wide range of carbonyl compounds so that aliphatic and aromatic aldehydes as well as aliphatic, cyclic and aromatic ketones may be introduced in the reaction (Table 1). The Darzens process was without side reactions, but was not stereoselective, and mixtures of $E$ and $Z$ isomers were frequently obtained with the $E$ form being preferred. Metallated diethyl chloromethylthiophosphonates have also served as precursors to diethyl 1,2epoxyalkylthiophosphonates. 6

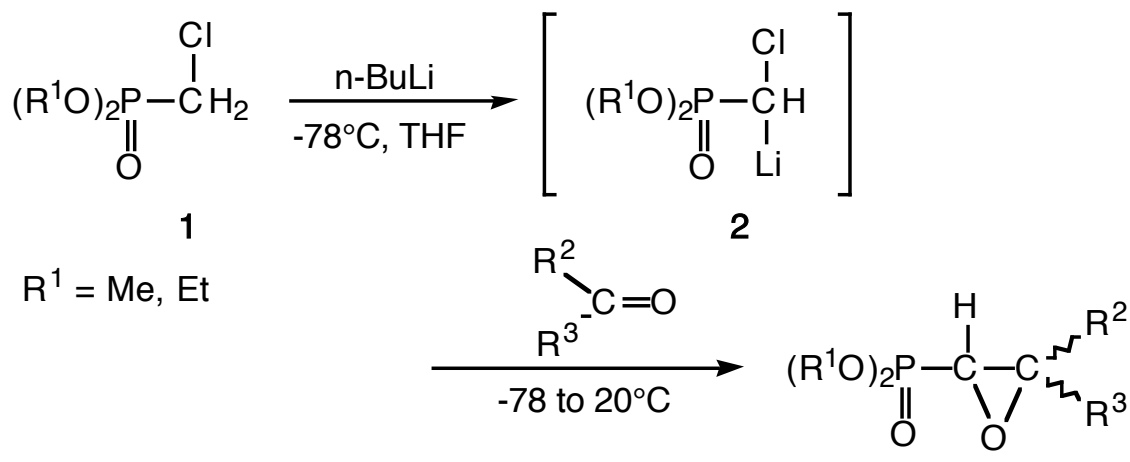

3

\section{Scheme 1}

Diethyl 1,2-epoxyalkanephosphonates ${ }^{6}$ : A 1.45 molar solution of $n$-butyllithium in hexane $(0.054$ mol $+5 \%)$ is placed in a three necked flask equipped with a stirrer, an addition funnel, a low temperature thermometer and a nitrogen inlet tube. An equal volume of tetrahydrofuran $(\sim 40 \mathrm{ml})$ is added to the cooled $\left(-20^{\circ}\right) \quad$ solution. Subsequently diethyl chloromethanephosphonate $(10 \mathrm{~g}, 0.054 \mathrm{~mol})$ in tetrahydrofuran $(15 \mathrm{ml})$ is added dropwise at $-70^{\circ} \mathrm{C}$. After $\sim 10 \mathrm{~min}$ the clear reaction mixture becomes turbid and the carbonyl compound $(0.054 \mathrm{~mol})$ in tetrahydrofuran $(10 \mathrm{ml})$ is added at $-75^{\circ}$ to $-70^{\circ}$. The mixture becomes clear, stirring is continued for $1 \mathrm{~h}$ at $-70^{\circ}$, and then the mixture is allowed to warm to room temperature within a few min. Stirring is continued at room temperature for $17 \mathrm{~h}$, water $(40 \mathrm{ml})$ is added, and the product is extracted into 1:1 ether / dichloromethane $(3 \mathrm{x}$ 
$50 \mathrm{ml}$ ). The combined organic layers are dried with magnesium sulfate, the solvent is removed under reduced pressure and the product is purified by vacuum distillation.

Table 1. Synthesis of dialkyl 1,2-epoxyalkylphosphonates by the Darzens reaction.

\begin{tabular}{|c|c|c|c|c|c|c|}
\hline 3 & $\mathrm{R}^{1}$ & $\mathrm{R}^{2}$ & $\mathrm{R}^{3}$ & Base/Solvent & Yield $(\%)$ & Ref. \\
\hline \multirow[t]{2}{*}{$\mathbf{a}$} & \multirow[t]{2}{*}{ Et } & \multirow[t]{2}{*}{$\mathrm{Me}$} & \multirow[t]{2}{*}{$\mathrm{Me}$} & n-BuLi/THF & 80 & 6 \\
\hline & & & & NaH/DMSO & 61 & 16 \\
\hline b & Et & $\mathrm{Et}$ & Et & n-BuLi/THF & 89 & 6 \\
\hline c & Et & $i-\operatorname{Pr}$ & $i-\operatorname{Pr}$ & n-BuLi/THF & 88 & 6 \\
\hline d & Et & $\mathrm{Me}$ & Et & $n$-BuLi/THF & 85 & 6 \\
\hline $\mathbf{e}$ & Et & $\mathrm{Me}$ & $i-\operatorname{Pr}$ & $n$-BuLi/THF & 86 & 6 \\
\hline $\mathbf{f}$ & Et & $\mathrm{Me}$ & $t-\mathrm{Bu}$ & n-BuLi/THF & 75 & 6 \\
\hline $\mathbf{g}$ & Et & $\mathrm{Me}$ & $i$-Bu & $n$-BuLi/THF & 81 & 6 \\
\hline $\mathbf{h}$ & Et & $\mathrm{Me}$ & $-\mathrm{CH}=\mathrm{CH}_{2}$ & $n$-BuLi/THF & 36 & 6 \\
\hline $\mathbf{i}$ & Et & $\mathrm{Me}$ & $\begin{array}{c}-\mathrm{C}=\mathrm{CH}_{2} \\
\mathrm{Me}\end{array}$ & $n$-BuLi/THF & 75 & 6 \\
\hline $\mathbf{j}$ & Et & $\mathrm{Me}$ & $-\mathrm{CH}(\mathrm{OMe})_{2}$ & $n$-BuLi/THF & 76 & 6 \\
\hline $\mathbf{k}$ & Et & $\mathrm{Me}$ & & $n$-BuLi/THF & 90 & 6 \\
\hline \multirow[t]{2}{*}{1} & \multirow[t]{2}{*}{ Et } & \multirow[t]{2}{*}{$\mathrm{Me}$} & & $n$-BuLi/THF & 51 & 6 \\
\hline & & & & $\mathrm{NaH} / \mathrm{DMSO}$ & - & 13 \\
\hline m & Et & $\mathrm{H}$ & $\mathrm{Me}$ & n-BuLi/THF & 65 & 6 \\
\hline $\mathbf{n}$ & Et & $\mathrm{H}$ & $i-\operatorname{Pr}$ & $n$-BuLi/THF & 66 & 6 \\
\hline $\mathbf{o}$ & Et & $\mathrm{H}$ & $i-\mathrm{Bu}$ & $n$-BuLi/THF & 57 & 6 \\
\hline $\mathbf{p}$ & Et & & $-\left(\mathrm{CH}_{2}\right)_{4}-$ & $n$-BuLi/THF & 76 & 6 \\
\hline $\mathbf{q}$ & $\mathrm{Me}$ & $\mathrm{Me}$ & $-\left(\mathrm{CH}_{2}\right)_{2} \mathrm{CH}(\mathrm{Me})_{2}$ & EtONa/ether & 37 & 5 \\
\hline \multirow{2}{*}{$\mathbf{r}$} & \multirow{2}{*}{ Et } & \multirow{2}{*}{$\mathrm{H}$} & & EtONa/ether & 31 & 5 \\
\hline & & & & $t-\mathrm{BuOK} / t-\mathrm{BuOH}$ & 43 & 5 \\
\hline \multirow{2}{*}{$\mathbf{S}$} & \multirow{2}{*}{$\mathrm{Me}$} & \multirow{2}{*}{$\mathrm{Me}$} & & EtONa/ether & 21 & 5 \\
\hline & & & & $t-\mathrm{BuOK} / t-\mathrm{BuOH}$ & 36 & 5 \\
\hline $\mathbf{t}$ & $\mathrm{Me}$ & $\mathrm{H}$ & & $t-\mathrm{BuOK} / t-\mathrm{BuOH}$ & 65 & 5 \\
\hline \multirow{3}{*}{$\mathbf{u}$} & \multirow{3}{*}{ Et } & \multirow{3}{*}{$\mathrm{H}$} & & EtONa/ether & 14 & 5 \\
\hline & & & & $t-\mathrm{BuOK} / t-\mathrm{BuOH}$ & 61 & 5 \\
\hline & & & & NaH/DMSO & - & 13 \\
\hline $\mathbf{v}$ & $\mathrm{Me}$ & $\mathrm{Me}$ & $\mathrm{Me}$ & $\mathrm{NaH} / \mathrm{DMSO}$ & - & 13 \\
\hline
\end{tabular}




\begin{tabular}{|c|c|c|c|c|c|c|}
\hline $\mathbf{w}$ & $\mathrm{Me}$ & $\mathrm{Ph}$ & $\mathrm{Ph}$ & $\mathrm{NaH} / \mathrm{DMSO}$ & - & 13 \\
\hline $\mathbf{x}$ & Et & $\mathrm{Ph}$ & $\mathrm{Ph}$ & $\mathrm{NaH} / \mathrm{DMSO}$ & - & 13 \\
\hline \multirow{2}{*}{$\mathbf{y}$} & \multirow{2}{*}{ Et } & \multirow{2}{*}{\multicolumn{2}{|c|}{$-\left(\mathrm{CH}_{2}\right)_{5-}^{-}$}} & $\mathrm{NaH} / \mathrm{DMSO}$ & - & 13 \\
\hline & & & & $\mathrm{NaNH}_{2} / \mathrm{C}_{6} \mathrm{H}_{6}$ & - & 14 \\
\hline $\mathbf{z}$ & $\mathrm{Me}$ & $\mathrm{H}$ & & $t-\mathrm{BuOK} / t-\mathrm{BuOH}$ & 68 & 5 \\
\hline aa & $\mathrm{Me}$ & $\mathrm{H}$ & & $t-\mathrm{BuOK} / t-\mathrm{BuOH}$ & 10 & 5 \\
\hline $\mathbf{a b}$ & $\mathrm{Et}$ & $\mathrm{H}$ & & $\mathrm{NaH} / \mathrm{C}_{6} \mathrm{H}_{6}$ & - & 15 \\
\hline
\end{tabular}

Several recent innovations have significantly extended the scope and synthetic utility of the classical Darzens reaction. For example, a useful supplement applicable to the formation of 1substituted-1,2-epoxyalkylphosphonates has been described to convert diethyl alkylphosphonates 4 into diethyl 1-substituted-1,2-epoxyalkylphosphonates 6 by a one-step process. ${ }^{7}$ Metallation of diethyl alkylphosphonates 4 with 2 eq. of $n$-BuLi in THF at low temperature followed by electrophilic chlorination using benzenesulfonyl chloride yields the diethyl 1-lithiochloroalkylphosphonates $\mathbf{5}$, which were converted into diethyl 1-substituted1,2-epoxyalkylphosphonates $\mathbf{6}$ by reaction with carbonyl compounds in moderate to good overall yields (30 to $80 \%$ ) (Scheme 2).

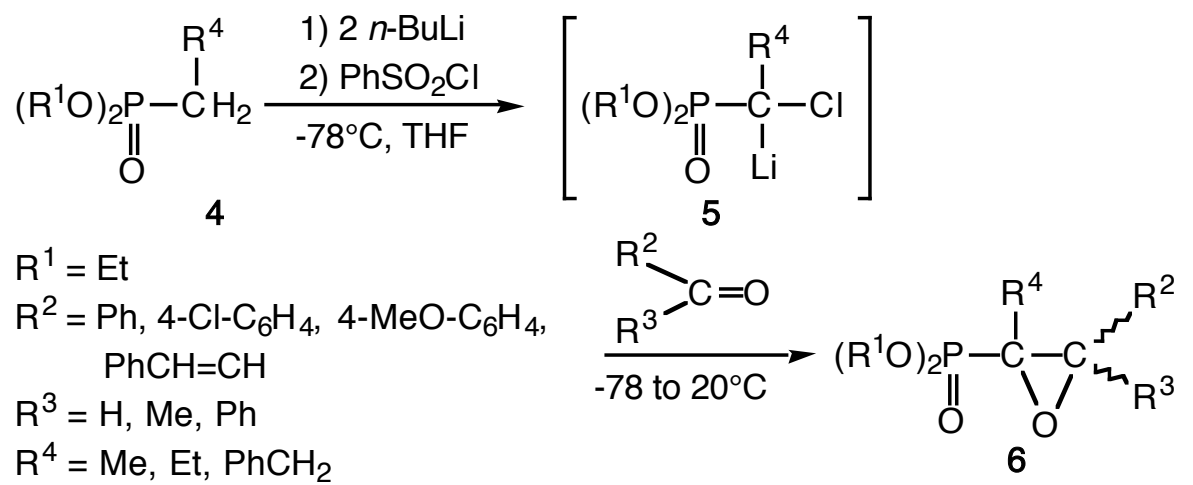

\section{Scheme 2}

Diehyl 1,2-epoxyalkanephosphonates ${ }^{7}$ : To a stirred solution of diethyl alkanephosphonate $(1 \mathrm{mmol})$ in dry THF ( $3 \mathrm{ml})$ is added $n$-butyllithium $\left(2.2 \mathrm{mmol}, 1.6 \mathrm{M}\right.$ in hexane) at $-78^{\circ} \mathrm{C}$ under nitrogen atmospere. After being stirred for $30 \mathrm{~min}$ at same temperature, benzenesulfonyl chloride $(1 \mathrm{mmol})$ and carbonyl compound $(1 \mathrm{mmol})$ are added successively and the mixture is allowed to warm with stirring to room temperature. Stirring is continued at room temperature for $15 \mathrm{~h}$, sat. $\mathrm{NH}_{4} \mathrm{Cl}$ solution $(10 \mathrm{ml})$ is added, and the mixture is extracted with ether $(3 \mathrm{x} 20$ $\mathrm{ml})$. The combined organic layer is dried with $\mathrm{MgSO}_{4}$, the solvent is removed under reduced pressure and the product is purified by column chromatography on silica gel (ethyl acetate / hexane $=1 / 1$ ).

The halogen-metal exchange reaction of diethyl 1,1-dichloroalkylphosphonates 7 with $n$-BuLi provides another convenient preparation of diethyl 1-lithio-1-chloroalkylphosphonates $\mathbf{5} .8$ 
This gives a somewhat higher yield of carbanion than is obtained by the chlorination procedure. For example, trapping of diethyl 1-lithio-1-chloroethylphosphonate $5\left(\mathrm{R}^{4}=\mathrm{Me}\right)$ with aliphatic or aromatic aldehydes and aliphatic ketones provides a suitable route to diethyl 1-methyl-1,2-epoxyalkylphosphonates $6\left(\mathrm{R}^{4}=\mathrm{Me}\right)$ in good yields $(61-81 \%)$ (Scheme 3$)$ as a mixture of $Z$ and $E$ isomers in approximately equal amounts. ${ }^{9}$

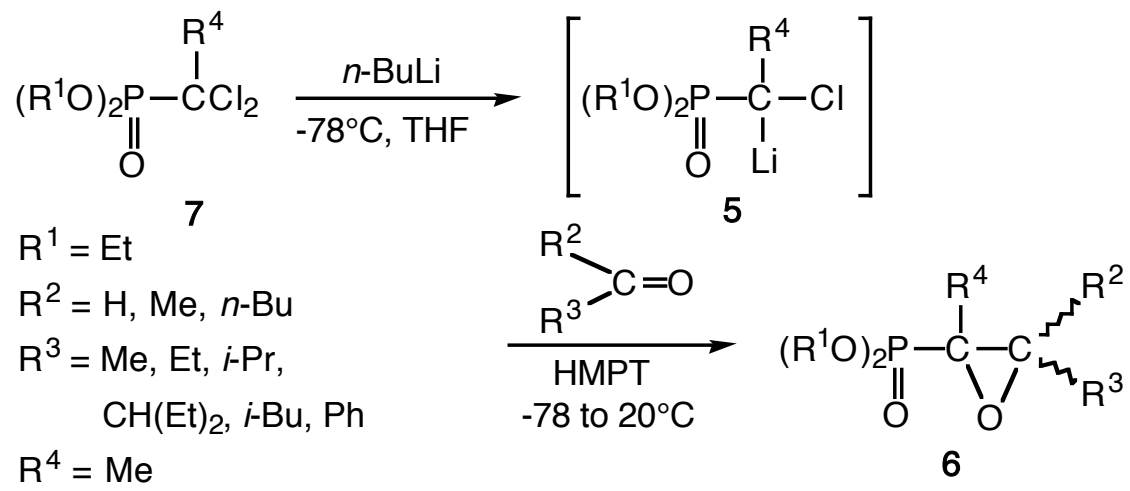

Scheme 3

Diethyl 1,2-dimethyl-1,2-epoxypropanephosphonate ${ }^{9}$ : A solution of diethyl 1,1-dichloroethane-phosphonate $(5.9 \mathrm{~g}, 25 \mathrm{mmol})$ in ether $(25 \mathrm{ml})$ and THF $(20 \mathrm{ml})$ is placed in a three necked flask equipped with a stirrer, addition funnel, low temperature thermometer, and nitrogen inlet tube, $n$-BuLi $(21.2 \mathrm{ml}$ of a $1.25 \mathrm{M}$ solution in ether, $5 \%$ excess), is added dropwise to the cooled solution $\left(-100^{\circ} \mathrm{C}\right)$ under nitrogen $(5 \mathrm{~min})$. When the addition is finished the temperature is allowed to reach $-85^{\circ} \mathrm{C}$ for $30 \mathrm{~min}$. Then, at $-90^{\circ} \mathrm{C}$, a solution of acetone $(1.5 \mathrm{~g}$, $\sim 26 \mathrm{mmol})$ in ether $(10 \mathrm{ml})$ is added and the cooling is removed. When the temperature has reached $-50^{\circ} \mathrm{C}, \mathrm{a}$ $1+1$ mixture $(10 \mathrm{ml})$ of HMPT-THF is added and stirring is continued for $30 \mathrm{~min}$ at $0^{\circ} \mathrm{C}$. Then, 2 normal sulfuric acid $(20 \mathrm{ml})$ is rapidly added and the mixture is extracted with ether $(3 \times 50 \mathrm{ml})$. The organic phase is washed with 1 normal sulfuric acid $(50 \mathrm{ml})$ and with saturated sodium chloride solution $(2 \times 100 \mathrm{ml})$, it is dried with magnesium sulfate, the solvents are removed at reduced pressure, and the oily residue is distilled in vacuo; yield: $4.5 \mathrm{~g}(80 \%)$; b.p. $70^{\circ} \mathrm{C} / 0.25$ torr.

A new technique for the formation of 1,2-epoxyalkylphosphonates $\mathbf{3}$ is based upon the reactivity towards aromatic aldehydes of electrochemically generated carbanion of diethyl chloromethylphosphonate $\mathbf{1}\left(\mathrm{R}^{1}=\mathrm{Et}\right)$ in DMF. ${ }^{10}$ The yield of $72 \%$ obtained with $p$-methoxybenzaldehyde was promising. However, the major disadvantage, which attends the use of the electrochemical route is the difficulty that may be encountered in the electrogeneration of species sufficiently basic to deprotonate the chloromethylphosphonates.

An interesting and useful variant of the Darzens reaction has been reported for the preparation of fosfomycin from diethyl chloromethylphosphonate $\mathbf{1}\left(\mathrm{R}^{1}=\mathrm{Et}\right) .{ }^{11}$ Nucleophilic substitution of the chlorine in diethyl chloromethylphosphonate with dimethyl sulfide gives the sulfonium salt $\mathbf{8}$, which may be further converted into its stable ylide by the use of $\mathrm{MeS}(\mathrm{O}) \mathrm{CH}_{2} \mathrm{Na}$. The use of the ylide in addition to acetaldehyde produces the diethyl 1,2-epoxypropylphosphonate 9, thus avoiding the problems associated with stability of chloromethylphosphonate carbanions (Scheme 4). 
<smiles>CCOP(=O)(CC)OCC(C)(C)CCl</smiles><smiles>CO[C@H](C)[C@H](C)OP(=O)(OC)C1OC1C</smiles>

\section{Scheme 4}

The use of diazomethane derivatives represents another modification of the Darzens reaction (Scheme 5). However, the reaction was not effective enough and remains undeveloped. ${ }^{12}$ Diphenyldiazomethane on reaction with dimethyl $\alpha$-ketophosphonates $\mathbf{1 0}$ undergoes reactions typical of carbonyl compounds to give the corresponding dimethyl 1-substituted-2,2diphenyl-1,2-epoxyethylphosphonates $\mathbf{1 1}$.

Dimethyl 1-(4-methoxyphenyl)-2,2-diphenyl-1,2-epoxyethylphosphonate ${ }^{17}$ : It was prepared by adding diphenyldiazomethane ( $2.7 \mathrm{~g}, 14$ mmole) with stirring over a 3 day period to $16 \mathrm{~g}$ (66 mmole) of dimethyl $p$ methoxybenzoylphosphonate. The reaction temperature was maintained at $62^{\circ} \mathrm{C}$, and the rate of addition determined by the disappearence of the red color of the diazomethane. Colorless crystals of epoxide precipitated. This material was recrystallized from benzene-hexane to afford $2.8 \mathrm{~g}(49 \%)$ of epoxide, mp 142.0-144. $0^{\circ} \mathrm{C}$.

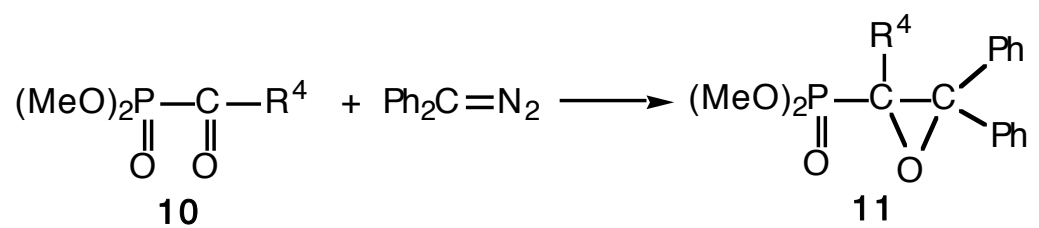

$\mathrm{R}^{4}=\mathrm{Me}, \mathrm{Ph}, 4-\mathrm{MeO}-\mathrm{C}_{6} \mathrm{H}_{4}, 4-\mathrm{Me}-\mathrm{C}_{6} \mathrm{H}_{4}, 4-\mathrm{Cl}-\mathrm{C}_{6} \mathrm{H}_{4}, 4-\mathrm{CN}-\mathrm{C}_{6} \mathrm{H}_{4}$

Scheme 5

\subsection{The reaction of sodium dialkylphosphite with $\alpha$-haloketones}

In connection with the reaction of $\alpha$-haloketones with nucleophiles, which is a standard epoxide synthesis, ${ }^{18}$ it is well recognized that reaction of $\alpha$-haloketones $\mathbf{1 3}$ with the appropriate phosphorus nucleophiles can constitute an interesting but somewhat limited method of synthesis of dialkyl 1,2-epoxyalkylphosphonates 6. Effectively, the conditions required for this procedure may not be compatible with the sensitive functionalities of $\alpha$ haloketones, and the reaction sometimes proceeds with a lack of regiospecificity to produce a mixture of phosphorus compounds. Thus, this reaction has been reported to give the epoxide alone, ${ }^{24,28}$ the vinyl phosphate alone, ${ }^{25,36}$ a mixture of the epoxide and vinyl phosphate, ${ }^{20,21,23}$ or a mixture of the epoxide and $\beta$-ketophosphonate. ${ }^{2,26,27,29} \mathrm{~A}$ large number of investigations have led to propose four types of mechanisms involving an initial attack of the phosphorus on: the halogen, ${ }^{31}$ the carbonyl oxygen, ${ }^{32}$ the $\alpha$-carbon bound to the halogen ${ }^{33}$ or on the carbonyl carbon. ${ }^{34,35}$ Formation of the vinyl phosphate, epoxyphosphonate and phosphate halohydrin is believed to result from attack by the 
phosphorus at the carbonyl carbon. Formation of the $\beta$-ketophosphonate results from attack at the $\alpha$-halo carbon. Alkali metal derivatives of dialkylphosphites $12(\mathrm{M}=\mathrm{Na}, \mathrm{K})$ attack $\alpha$ haloketones $13(\mathrm{X}=\mathrm{Cl}, \mathrm{Br})$ primarily at the carbonyl carbon atom forming an alkoxide anion 14, which displaces the $\beta$-halogen to give the dialkyl 1,2-epoxyalkylphosphonates 6 (Scheme 6) with reasonable yields in the range 55 to $71 \%$ (Table 2). In some cases, however, formation of vinyl phosphate $\mathbf{1 5}$ can be a competing reaction. ${ }^{20,21,23,30}$ This procedure appears to be limited to the synthesis of epoxides having only one non-hydrogen $\beta$-substituent since the $\alpha$ halo carbon cannot be tertiary, the vinyl phosphate being the main product. ${ }^{20-22,36,37}$

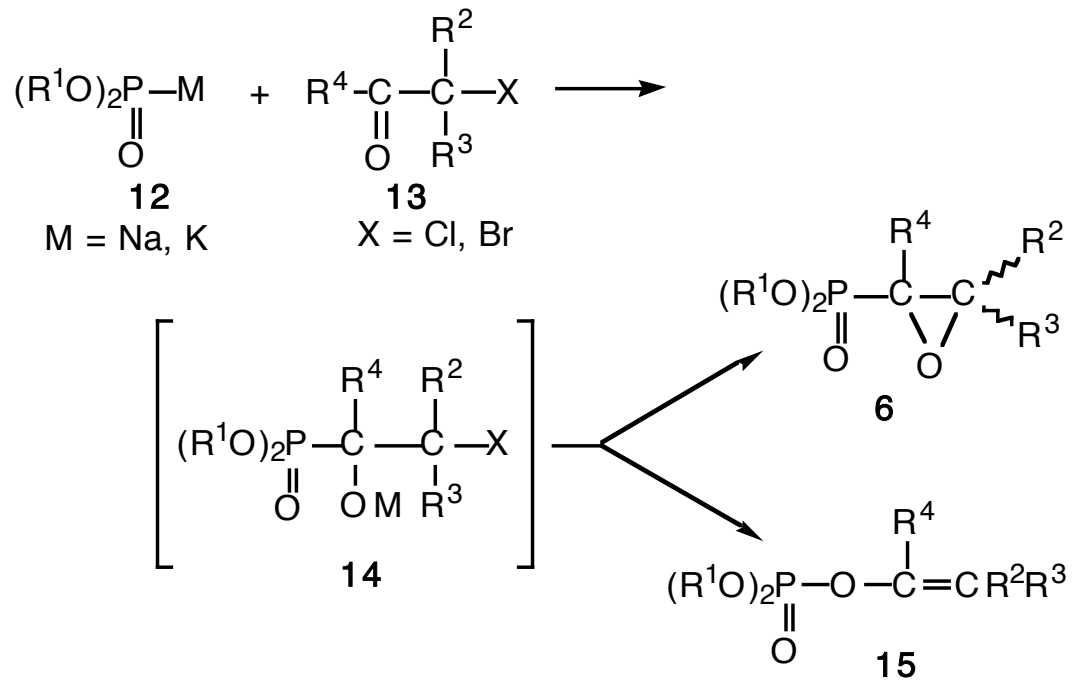

\section{Scheme 6}

1-Méthyl-1,2-epoxyéthylphosphonate de diéthyle ${ }^{24}$ : Dans un tricol de $500 \mathrm{ml}$ muni d'une ampoule isobare, d'un agitateur, d'un thermomètre, et isolé de l'extérieur par un tube à $\mathrm{CaCl}_{2}$, on place $0,3 \mathrm{M}$ de phosphite sodé en solution éthérée. On refroidit à $-70^{\circ} \mathrm{C}$ à l'aide d'un mélange carboglace-acétone. On ajoute alors goutte à goutte une solution $0,3 \mathrm{M}$ de chloracétone diluée dans son volume d'éther anhydre. On maintient le Dewar toute la nuit. Le lendemain matin, la température est de $30^{\circ} \mathrm{C}$. On supprime le refroidissement, on laisse le mélange revenir progressivement à température ordinaire. On chauffe ensuite $2 \mathrm{~h}$ à reflux. La minéralisation qui devait se produire n'apparaît pas. La solution laiteuse est très difficile à centrifuger. On ajoute $150 \mathrm{ml}$ de DMF et ayant placé une petite colonne, l'éther est distillé jusqu'à ce que la température atteigne $110^{\circ} \mathrm{C}$. On adapte alors un réfrigérant ascendant, et cette température est maintenue pendant $1 \mathrm{~h}$. Il se forme une importante minéralisation. Après refroidissement, on centrifuge, on chasse le DMF à la trompe et distille. Une rectification soignée donne E.b. $=75^{\circ} \mathrm{C} / 0,6 \mathrm{~mm} \mathrm{Hg} ; \mathrm{Pds}=35 \mathrm{~g}$.

Table 2. Synthesis of dialkyl 1,2-epoxyalkylphosphonates from sodium dialkylphosphites and $\alpha$-haloketones.

\begin{tabular}{|c|c|c|c|c|c|c|c|}
\hline 6 & $\mathrm{R}^{1}$ & $\mathrm{R}^{2}$ & $\mathrm{R}^{3}$ & $\mathrm{R}^{4}$ & $X$ & Yield $(\%)$ & Ref. \\
\hline $\mathbf{a}$ & $\mathrm{Me}$ & $\mathrm{H}$ & $\mathrm{H}$ & $\mathrm{Me}$ & $\mathrm{Cl}$ & 74.4 & 45 \\
\hline b & $\mathrm{Me}$ & $\mathrm{C}_{6} \mathrm{H}_{5}$ & $\mathrm{H}$ & $\mathrm{C}_{6} \mathrm{H}_{5}$ & $\mathrm{Cl}$ & - & 14 \\
\hline c & $\mathrm{Me}$ & $\mathrm{C}_{6} \mathrm{H}_{5}$ & $\mathrm{H}$ & $4-\mathrm{MeO}-\mathrm{C}_{6} \mathrm{H}_{4}$ & $\mathrm{Cl}$ & - & 14 \\
\hline d & $\mathrm{Et}$ & $\mathrm{H}$ & $\mathrm{H}$ & $\mathrm{C}_{6} \mathrm{H}_{5}$ & $\mathrm{Cl}$ & 56 & 23 \\
\hline
\end{tabular}




\begin{tabular}{cccccccc} 
e & $\mathrm{Et}$ & $\mathrm{H}$ & $\mathrm{H}$ & $\mathrm{Me}$ & $\mathrm{Cl}$ & 76.6 & 45 \\
& & & & $\mathrm{Cl}$ & 27 & 22 \\
$\mathbf{f}$ & $\mathrm{Et}$ & $\mathrm{H}$ & $\mathrm{H}$ & $\mathrm{Ct}$ & $\mathrm{Cl}$ & 65 & 24 \\
$\mathbf{g}$ & $\mathrm{Et}$ & $\mathrm{H}$ & $\mathrm{H}$ & $\mathrm{C}_{6} \mathrm{H}_{5}$ & $\mathrm{Br}$ & - & 24 \\
$\mathbf{h}$ & $\mathrm{Et}$ & $\mathrm{H}$ & & $-\left(\mathrm{CH}_{2}\right)_{3}-$ & $\mathrm{Cl}$ & - & $20 \mathrm{~b}$ \\
$\mathbf{i}$ & $\mathrm{Et}$ & $\mathrm{H}$ & & $-\left(\mathrm{CH}_{2}\right)_{4}-$ & $\mathrm{Cl}$ & - & 21 \\
& & & & $\mathrm{Br}$ & & $20 \mathrm{a}$ \\
$\mathbf{j}$ & $\mathrm{Et}$ & $\mathrm{Me}$ & $\mathrm{H}$ & $\mathrm{Me}$ & $\mathrm{Cl}$ & 52.6 & 45 \\
& & & & $\mathrm{Br}$ & - & 22 \\
$\mathbf{k}$ & $\mathrm{Et}$ & $\mathrm{Me}$ & $\mathrm{H}$ & $\mathrm{C} 6 \mathrm{H}_{5}$ & $\mathrm{Br}$ & - & $20 \mathrm{~b}$ \\
$\mathbf{l}$ & $\mathrm{Et}$ & $\mathrm{C}_{6} \mathrm{H}_{5}$ & $\mathrm{H}$ & $\mathrm{Me}$ & $\mathrm{Cl}$ & - & 14 \\
$\mathbf{m}$ & $\mathrm{Et}$ & $\mathrm{C}_{6} \mathrm{H}_{5}$ & $\mathrm{H}$ & $t-\mathrm{Bu}$ & $\mathrm{Cl}$ & - & 14 \\
$\mathbf{n}$ & $i-\mathrm{Pr}$ & $\mathrm{H}$ & $\mathrm{H}$ & $\mathrm{Me}$ & $\mathrm{Cl}$ & 68.7 & 45 \\
& & & & $\mathrm{H}$ & $\mathrm{Cl}$ & - & 22 \\
$\mathbf{0}$ & $n-\mathrm{Bu}$ & $\mathrm{H}$ & & $\mathrm{Cl}$ & 69.1 & 45 \\
& & & & $\mathrm{Cl}$ & 69 & 24 \\
\hline
\end{tabular}

An alternative procedure for the preparation of dialkyl 1,2-epoxyalkylphosphonates 6 from $\alpha$ haloketones is the action of sodium methoxide ( 1 eq.) on a mixture of $\alpha$-chloroketones $\mathbf{1 3}$ $(\mathrm{X}=\mathrm{Cl})$ and dimethyl- or diethylphosphite $\left(1\right.$ eq.) in methanol at room temperature. ${ }^{37}$ The reproductible yields of 53 to $84 \%$ obtained by this technique represent a significant improvement over the yields of 30 and $63 \%$ reported for the one-step reaction of $\alpha$ chloroketones with sodium diethylphosphite. This procedure appears to give only the epoxides with aliphatic $\alpha$-chloroketones and attempts to form the epoxide by reaction of $\alpha$ chloroacetophenone with dimethylphosphite resulted in the formation of dimethyl 1phenylvinylphosphate. However, in spite of the difficulties frequently encountered in the choice of the $\alpha$-chloroketones, this facile and convenient procedure is a useful variant of the classical approach as illustrated by the results gathered in the Table 3 .

Table 3. Synthesis of dialkyl 1,2-epoxyphosphonates from dialkylphosphites, $\alpha$-chloroketones and sodium methoxide.

\begin{tabular}{ccccccc}
\hline $\mathbf{6}$ & $\mathrm{R}^{1}$ & $\mathrm{R}^{2}$ & $\mathrm{R}^{3}$ & $\mathrm{R}^{4}$ & Yield (\%) & Ref. \\
\hline $\mathbf{a}$ & $\mathrm{Me}$ & $\mathrm{H}$ & $\mathrm{H}$ & $\mathrm{Me}$ & 84 & 37 \\
$\mathbf{e}$ & $\mathrm{Et}$ & $\mathrm{H}$ & $\mathrm{H}$ & $\mathrm{Me}$ & 83 & 37 \\
$\mathbf{p}$ & $\mathrm{C}_{6} \mathrm{H}_{5} \mathrm{CH}_{2}$ & $\mathrm{H}$ & $\mathrm{H}$ & $\mathrm{Me}$ & 48 & 37
\end{tabular}




\begin{tabular}{ccccccc}
$\mathbf{q}$ & $\mathrm{Me}$ & $\mathrm{H}$ & $\mathrm{H}$ & $t-\mathrm{Bu}$ & 87 & 37 \\
$\mathbf{r}$ & $\mathrm{Me}$ & $\mathrm{H}$ & $\mathrm{Me}$ & $t-\mathrm{Bu}$ & 70 & 37 \\
$\mathbf{s}$ & $\mathrm{Me}$ & $\mathrm{H}$ & $\mathrm{Me}$ & $\mathrm{Me}$ & 53 & 37 \\
$\mathbf{t}$ & $\mathrm{Me}$ & $\mathrm{H}$ & \multicolumn{2}{l}{$-\left(\mathrm{CH}_{2}\right)_{4}-$} & 33 & 37 \\
\hline
\end{tabular}

Dimethyl 1,2-epoxy-2-propylphosphonate ${ }^{37}$ : A solution of sodium methoxide was prepared by dissolving 0.06 $\mathrm{mol}(1.37 \mathrm{~g})$ of sodium in $25 \mathrm{ml}$ of methanol. The sodium methoxide was then added dropwise over a period of $15 \mathrm{~min}$ to a mixture of $0.06 \mathrm{~mol}(5.55 \mathrm{~g})$ of chloroacetone and $0.06 \mathrm{~mol}(6.60 \mathrm{~g})$ of dimethyl phosphite in $5 \mathrm{ml}$ of methanol at room temperature. After stirring for $1 \mathrm{~h}$ the solution was filtered, distilled to remove methanol, and refiltered. Ether was then added to precipitate any remaining sodium chloride. The solution was filtered again and ether evaporated off. A short-pass distillation gave the title compound: b.p. $75-76^{\circ} \mathrm{C}(0.7 \mathrm{~mm} \mathrm{Hg})$.

The reaction between diethylphosphite and $\alpha$-chloroketones $13(\mathrm{X}=\mathrm{Cl})$ can also be accomplished by fluoride ion-deprotonation reaction in DMF (dry $\mathrm{KF}$ or $\mathrm{KF} \cdot 2 \mathrm{H}_{2} \mathrm{O}$ are fluoride ion source), which proves a non-basic route to diethyl 1,2-epoxyalkylphosphonates. However, the application of this technique provides a mixture of 1,2-epoxyphosphonate (about 50\%) and vinyl phosphate (about 30\%) whatever the $\alpha$-chloroketones. ${ }^{38}$

The reaction conditions required for the preparation of halogenoketones frequently may not be compatible with the sensitive functionalities that are present in complex polyfunctional molecules. Recent innovations in the standard synthetic procedure using $\alpha$-haloketones have featured the use of a new class of leaving groups, $\alpha$-tosyloxyketones ${ }^{39-43}$ For example, a relatively general procedure for the quantitative generation of dialkyl 1,2-epoxyphosphonates $\mathbf{1 7}$ possessing a sugar or a steroid appendage using $\alpha$-tosyloxyketones $\mathbf{1 6}$ has been employed. Generation of the epoxides may be conveniently executed under a variety of reaction conditions. They include sodium diethylphosphite in EtOH at reflux (69\%), ${ }^{39}$ diethylphosphite in the two-phase system $\mathrm{CH}_{2} \mathrm{Cl}_{2} / \mathrm{NaOH} 50 \% / \mathrm{TBAC}$ at room temperature ${ }^{41}$ or diethylphosphite in $\mathrm{MeOH}$ in the presence of $\mathrm{DBU}$ at $0^{\circ} \mathrm{C}(62-90 \%)^{42 \mathrm{a}, 42 \mathrm{~b}, 43}$ (Scheme 7). This attractive procedure appears as a useful modification having a great synthetic utility since the leaving group is introduced in mild conditions by merely treating the sensitive substrat containing a primary alcohol with $\mathrm{TsCl}$ in the presence of pyridine. ${ }^{43}$ 


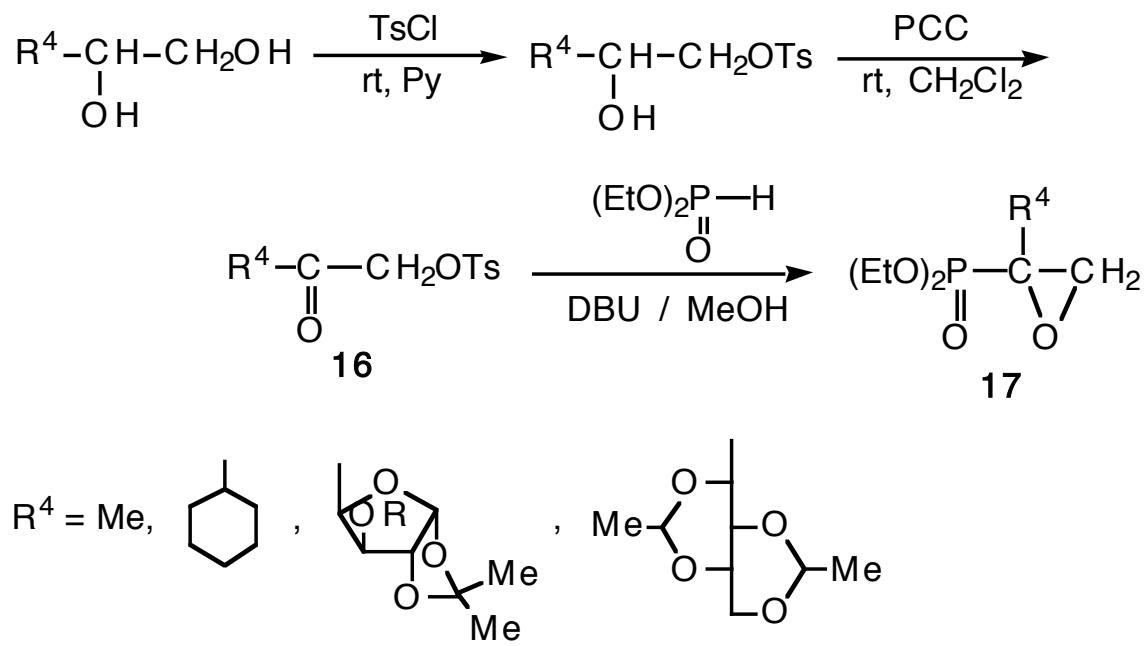

\section{Scheme 7}

(5R or 5S)-5,6-anhydro-3-O-benzyl-5- $C$-(dimethoxyphosphinyl)-1,2- $O$-isopropylidene- $\alpha-D-x y l o-$ hexofuranose $^{42}$ : To a mixture of 3- $O$-benzyl-1,2- $O$-isopropylidene-6- $O$ - $p$-tolylsulfonyl- $\alpha$ - $D$ - $x y l o$-hexofuranose $(5.6 \mathrm{~g})$ and dimethyl phosphite $(1.5 \mathrm{~g})$ in methanol $(10 \mathrm{ml})$ was added DBU $(2.1 \mathrm{~g})$ during $1 \mathrm{~h}$ at $0^{\circ} \mathrm{C}$, and the solution was kept in a refrigerator for $48 \mathrm{~h}$. The methanol and unreacted dimethyl phosphite were removed in vacuo, and then a solution of the residue in chloroforme was successively washed with aqueous sodium hydrogencarbonate and water, dried (sodium sulfate), and evaporated, to afford a syrup, which was chromatographied in a column of silica gel, using 1:2 (v/v) ethyl acetate-petroleum ether as the eluant. The fractions were suitably pooled, and evaporated in vacuo to give a syrup ( $3.4 \mathrm{~g}, 70 \%)$, which crystallized after 2 days; m.p. $107-108^{\circ} \mathrm{C}$ (ethyl acetate-hexane).

Another variation reports a one-pot synthesis of diethyl 1-(perfluoroalkyl)-1,2epoxyalkylphosphonates 19 using the nucleophilic attack of lithium diethylphosphite on the carbonyl carbon atom of the perfluorinated $\beta$-oxophosphonium salts 18 (Scheme 8). ${ }^{44}$ The resulting intermediate can eliminate in two directions. When the oxygen anion with the least sterically hindered position attacks the neighbouring carbon atom it gives, after elimination of triphenylphosphine (anti fashion), the diethyl 1-(perfluoroalkyl)-1,2-epoxyalkylphosphonates 19 in moderate yields (42-51\%). The formation of the $\alpha$-(perfluoroalkyl)vinylphosphonates 20 by attack at phosphorus (syn fashion) can be a competing reaction. The results indicate that the selectivity could be controlled to produce exclusively either epoxyphosphonates or vinylphosphonates depending on steric factors $\left(\mathrm{R}^{2}, \mathrm{R}^{3}\right)$ and the base used. 


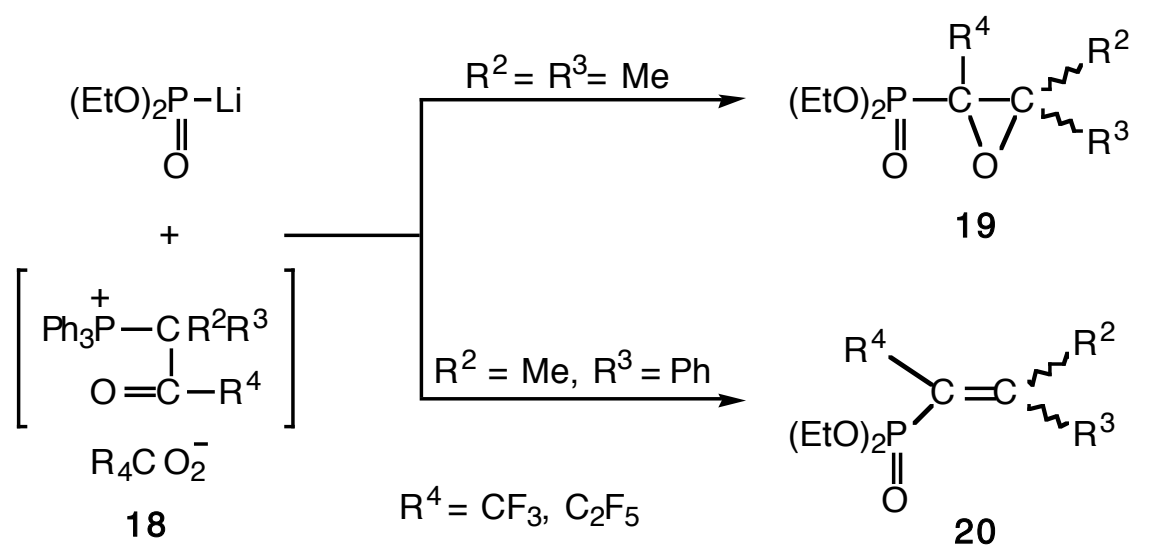

Scheme 8

Diethyl (3,3-dimethyl-2-pentafluoroethyloxiran-2-yl)phosphonate ${ }^{44}: \quad n$-Butyllithium $\quad(3.0 \quad$ mmol $)$ or methyllithium $(3.0 \mathrm{mmol})$ in dry tetrahydrofuran (THF) was added dropwise to a stirred suspension of the phosphonium salt $18(3.0 \mathrm{mmol})$ in absolute THF $(30 \mathrm{ml})$ at $-20^{\circ} \mathrm{C}$ under nitrogen. The mixture was stirred for $30 \mathrm{~min}$ at $0^{\circ} \mathrm{C}$ and cooled to $-78^{\circ} \mathrm{C}$; the perfluoroalkanoic anhydride $(2.5 \mathrm{mmol})$ was slowly added until the characteristic ylidic colour had disappeared. The mixture was stirred at $-78^{\circ} \mathrm{C}$ for $5 \mathrm{~min}$ and a solution of diethyl lithium phosphite [prepared by the reaction of ethyl hydrogen phosphite $(0.41 \mathrm{~g}, 3.0 \mathrm{mmol})$ and methyllithium $(3.0 \mathrm{mmol})$ in THF $(10 \mathrm{ml})$ for $30 \mathrm{~min}$ at $-78^{\circ} \mathrm{C}$ ] was slowly added. The mixture was allowed to warm to room temperature, stirred for a further $2 \mathrm{~h}$, and diluted with light petroleum (b.p. $60-90^{\circ} \mathrm{C}$ ). Filtration and evaporation of filtrate gave a residue, which was purified by column chromatography on silica gel with light petroleum (b.p. $\left.60-90^{\circ} \mathrm{C}\right)$-ethyl acetate $(10: 1)$ as eluant to give the title product: yield $42 \%$; b.p. $84^{\circ} \mathrm{C} / 2 \mathrm{~mm} \mathrm{Hg}$.

The most recent development in the field has featured the use of phase transfer catalyst conditions in the preparation of dialkyl 1,2-epoxyalkylphosphonates from dialkylphosphites and $\alpha$-haloketones $\mathbf{1 3}(\mathrm{X}=\mathrm{Cl}) .{ }^{45} \mathrm{~A}$ first procedure uses potassium carbonate in excess as base, and a second a mixture of potassium carbonate and sodium hydrogen carbonate, TBAB being introduced as phase transfer catalyst. Each reaction was carried out in the absence of solvent, the liquid phase being formed by the starting reagents. This method does not improve the yields of dialkyl 1,2-epoxyalkylphosphonates, which are roughly comparable to those previous reported. However, the absence of undesired side products, which usually accompany this reaction renders this methodology a viable alternative to the methods, which require the use of a solvent.

\subsection{The reaction of dialkyl halohydrinphosphonates and related structure with bases}

In addition to the two previous methodologies, there is a technique, which employs the conversion of halohydrinphosphonates into epoxyphosphonates by formation of an alkoxide anion. This two-step procedure appears to be limited to the synthesis of dialkyl 1,2epoxyethylphosphonates having hydrogens or only one non-hydrogen substituent. Formation of halohydrinphosphonates can be accomplished by two procedures, which exploit either the condensation of a dialkylphosphite with an $\alpha$-chlorocarbonyl compound or the halohydroxylation of a vinylphosphonate. The reaction of dialkylphosphites proceeds upon heating for a long time with $\alpha$-chloroketones at $100-165^{\circ} \mathrm{C}$ with a catalyst $(\mathrm{MeONa} / \mathrm{MeOH})^{19}$ 
or at $100-120^{\circ} \mathrm{C}$ without catalyst, 47 and with chloroacetaldehyde 46 at $100^{\circ} \mathrm{C}$ without any catalyst to give, in 50 to $100 \%$ yields, the chlorohydrinphosphonates having the hydroxyl group in the $\alpha$ position. The reaction between diethylphosphite and chloroacetaldehyde can proceed also at room temperature in the presence of catalytic amount of triethylamine. ${ }^{48}$

Diethyl 2-chloro-1-hydroxyethylphosphonate ${ }^{48}$ : A mixture of diethyl phosphite (27.6 g) and chloroacetaldehyde $(15.6 \mathrm{~g})$ was stirred at room temperature for $3 \mathrm{~h}$ in the presence of a few drops of triethylamine. Distillation in vacuo of the resultant reaction mixture gave $23.7 \mathrm{~g}(63 \%)$ of the title compound; b.p. $=116-118^{\circ} \mathrm{C} / 0.06 \mathrm{~mm} \mathrm{Hg}$.

The halohydroxylation method has been developed for exploiting the reactivity of the double bond present in the dialkyl vinyl- and propenylphosphonates. The preparation of the halohydrins of diethyl vinylphosphonate 21, which failed to be accomplished using Nbromosuccinimide or N-bromoacetamide, was achieved on large scale by treatment of diethyl vinylphosphonate $\mathbf{2 1}$ with sodium hypochlorite or hypobromite in aqueous medium at $\mathrm{pH}<3$ to give the halohydrins 22 with the hydroxyl group in the $\beta$ position (anti Markovnikoff addition) having a $95 \%$ purity for the chlorohydrin and a $65-85 \%$ purity for the bromohydrin (Scheme 9). ${ }^{49}$ As a consequence of the acid conditions, the preparation of halohydrins 22 was generally accompanied by the formation of undesired diethyl 1,2-dihalogenophosphonates 23. 49

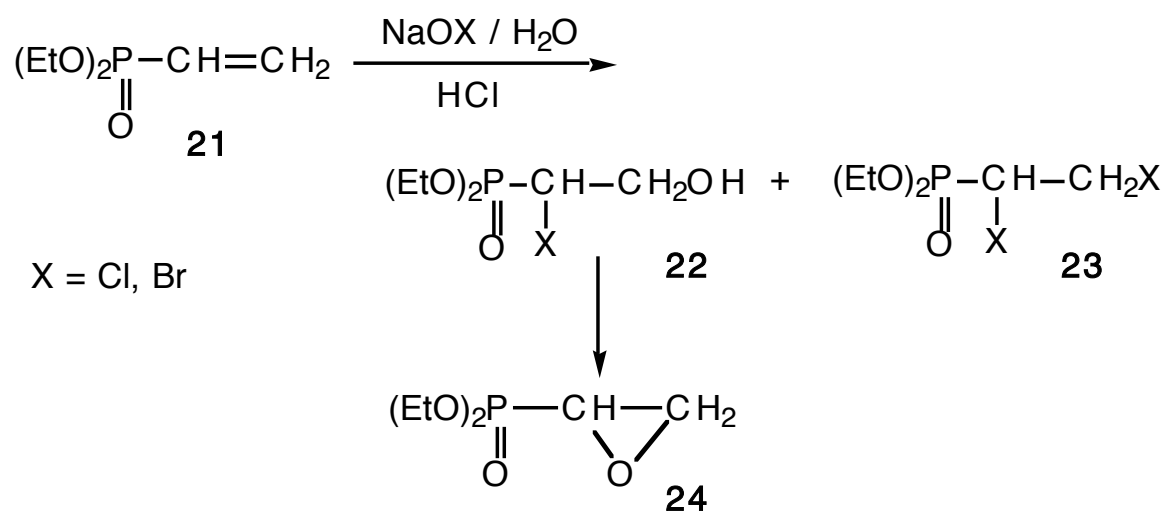

Scheme 9

1-Chloro-2-hydroxyéthylphosphonate de diéthyle ${ }^{49}$ : Dans un erlenmeyer muni d'une vive agitation magnétique, on place 0,1 mole de diéthyl vinylphosphonate dissous dans $700 \mathrm{ml}$ d'eau. La solution est portée à un $\mathrm{pH}<3$ par addition d' $\mathrm{HCl}$ concentré $(\mathrm{d}=1,19)$. On ajoute alors par petites portions $(\sim 15 \mathrm{ml})$ la solution d'hypochlorite de sodium, tout en maintenant le $\mathrm{pH}$ de la solution $\leq 3$ par addition simultanée d'HCl concentré. La réaction est considérée comme terminée lorsque le test à l'IK est positif après $15 \mathrm{mn}$ d'attente après la dernière addition de $\mathrm{NaOCl}$. (test à l'iodure de potassium dans un tube à essai, verser $1 \mathrm{ml}$ du milieu réactionnel et $1 \mathrm{ml}$ d'une solution à $10 \%$ d'IK. L'apparition d'une coloration jaune-brun atteste la présence d'acide hypohalogéneux). La quantité habituelle d'hypochlorite de sodium additionnée est de l'ordre de 50 à $55 \mathrm{ml}$ et celle de $\mathrm{HCl}$ environ $10 \mathrm{ml}$. Une fois l'addition de $\mathrm{NaOCl}$ terminée, le milieu est extrait par 6 × $50 \mathrm{ml}$ de $\mathrm{CH}_{2} \mathrm{Cl}_{2}$ et $100 \mathrm{ml} \mathrm{de} \mathrm{CHCl}_{3}$. Les phases organiques sont rassemblées et séchées sur $\mathrm{Na}_{2} \mathrm{SO}_{4}$ anhydre. Après évaporation des solvants, le résidu est distillé sous vide de la pompe. Le distillat est identifié comme un mélange des composés 22 et 23. 22: $\mathrm{Eb} .=105-108^{\circ} \mathrm{C} / 0,05 \mathrm{mmHg} ; \mathrm{Rdt}=86 \%$. 23: $\mathrm{Eb} .=92^{\circ} \mathrm{C} / 0,05 \mathrm{mmHg}$. 
Synthetic reactions, which result in the bromohydroxylation of the monoester of propenylphosphonate 50 with $\mathrm{N}$-bromoacetamide in water at $15^{\circ} \mathrm{C}$ and in the chloro- or bromohydroxylation of the diacid with N-chloro- or bromosuccinimide, were particularly useful to provide in good conditions the two isomeric threo-halohydrins, which can be separated prior to epoxidation. For example, crystallization from acetone of the mixture of diastereomeric bromohydrins prepared by bromohydroxylation of the monoester of propenylphosphonate provided the preferred threo-bromohydrin in diastereomerically pure form. 50

A variety of procedures have been developed to effect the conversion of $\alpha$ - or $\beta$-hydroxy halohydrins into 1,2-epoxyalkylphosphonates (NaH / THF; ${ }^{49} \mathrm{KOH} / \mathrm{THF} ;{ }^{49} \mathrm{EtO}^{-}$/ EtOH; 49 $\mathrm{KOH} / \mathrm{EtOH} ;{ }^{19,46,47,49} \mathrm{~K}_{2} \mathrm{CO}_{3} / \mathrm{MeOH}$ or $\mathrm{EtOH} ;{ }^{49} \mathrm{NaOH} / \mathrm{CH}_{2} \mathrm{Cl}_{2}$ / $\mathrm{TBAS}^{49}$ ). Generally, bromohydrinphosphonates give better results than corresponding chlorohydrinphosphonates. The phase transfert catalysis using the chlorohydrin $22(\mathrm{X}=\mathrm{Cl})$ of diethyl vinylphosphonate and concentrated $(50 \%)$ sodium hydroxyde at room temperature has been found to be the method of choice for preparing the diethyl 1,2-epoxyethylphosphonate 24 (74\%) on large scale (Scheme 9).49 The methods using alkoxide anion or $\mathrm{KOH}$ in alcohol tend to be accompanied by important monodealkylation at carbon ester. The preferred threobromohydrin obtained from propenylphosphonic acid was converted to epoxide by reaction with $\mathrm{MeONa}$ in $\mathrm{MeOH}$ at $40^{\circ} \mathrm{C} .50$

Diethyl 1,2-epoxyethylphosphonate ${ }^{48}$.

Method A : An ethanolic solution of $32 \mathrm{~g}$ of potassium hydroxide was added dropwise with stirring to a solution of the chlorohydrin $(124 \mathrm{~g})$ in ethanol $(300 \mathrm{ml})$ at $4-6^{\circ} \mathrm{C}$. Stirring was continued at room temperature for $10 \mathrm{~h}$. The mixture was then filtered, concentrated, and distilled in vacuo; yield: $57.6 \mathrm{~g}(54 \%)$.

Method B : An ethanolic solution of $19.2 \mathrm{~g}$ of sodium ethoxide was added dropwise with stirring to a solution of the chlorohydrin $(60 \mathrm{~g})$ in ethanol $(300 \mathrm{ml})$ at $10-18^{\circ} \mathrm{C}$. Stirring was continued at room temperature for $7 \mathrm{~h}$. The mixture was then filtered, concentrated, and distilled in vacuo; yield: $28.6 \mathrm{~g}(56 \%)$.

Method C : An aqueous solution of $10 \mathrm{~g}$ of potassium hydroxide was added dropwise with stirring to the chlorohydrin $(30.5 \mathrm{~g})$ at room temperature. Stirring was continued for $5 \mathrm{~h}$. The mixture was then concentrated, extracted with ether, the ether distilled, and the residue distilled in vacuo; yield: $5.7 \mathrm{~g}(23 \%)$, b.p. $=86-89^{\circ} \mathrm{C} / 2$ $\mathrm{mm} \mathrm{Hg}$.

Oxidation of the tetraethyl ethenylidene-1,1-diphosphonate 25 with aqueous $\mathrm{NaOCl}$ gives directly the tetraethyl oxiranylidene-1,1-diphosphonate $\mathbf{2 6}$ via nucleophilic Michael $\beta$ addition of the hypochlorite anion followed by ring closure (Scheme 10). ${ }^{51}$ Preparation of the tetrasodium salt $\mathbf{2 8}$ of the corresponding epoxide was accomplished in a two step process through the bromohydrin 27 . The latter was prepared from 25 by treatment of the double bond with $\mathrm{Br}_{2} / \mathrm{H}_{2} \mathrm{O}$, followed by ring closure by addition to a concentrated solution of $\mathrm{NaOH}$. 


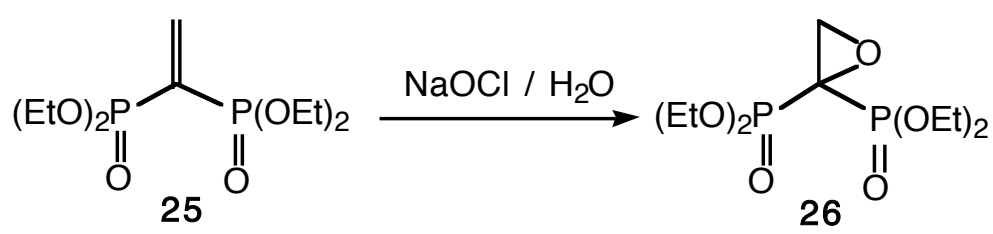

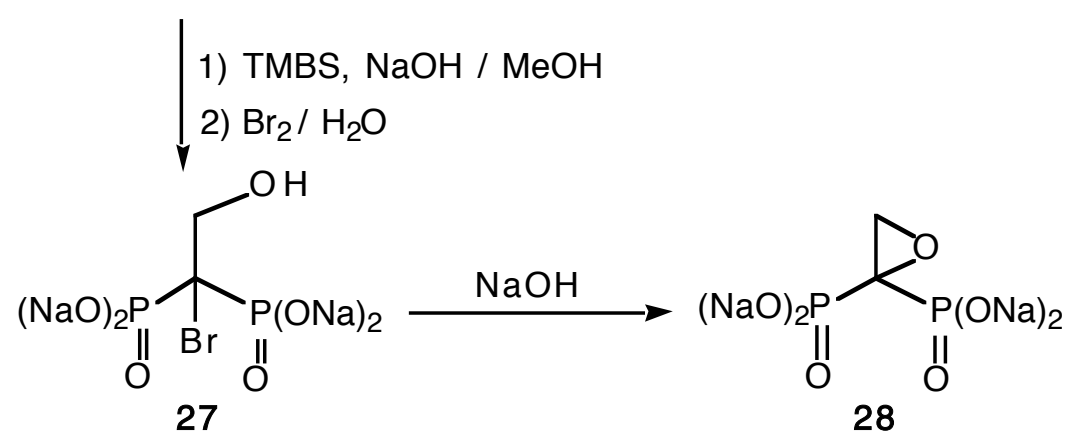

Scheme 10

Oxidation of the methylidene double bond in triethyl $\alpha$-phosphonoacrylate $\mathbf{2 9}$ has been investigated in details using $\mathrm{O}_{2}$, catalytic $\mathrm{RuO}_{4}$ (made in situ from $\mathrm{RuO}_{2} / \mathrm{NaOCl}$ or $\mathrm{RuO}_{2}$ / $\mathrm{NaIO}_{4}$ ) or stoichiometric $\mathrm{RuO}_{4}$ (Scheme 11).52 Treatment of triethyl $\alpha$-phosphonoacrylate 29 on large scale in a two-phase $\left(\mathrm{CCl}_{4} / \mathrm{H}_{2} \mathrm{O}\right)$ reaction mixture with catalytic $\mathrm{RuO}_{4}$ using $\mathrm{NaOCl}$ as co-oxidant or with $\mathrm{NaOCl}$ alone at room temperature produces triethyl $\alpha$ phosphonoacrylate oxide 30 in up to $79 \%$ isolated yield. As above, epoxidation of the double bond would begin with nucleophilic addition of the $\mathrm{ClO}^{-}$followed by ring closure. When $\mathrm{NaOCl}$ was replaced with $\mathrm{NaIO}_{4}$ as the $\mathrm{RuO}_{2}$ reoxidant in a two-phase $\left(\mathrm{CHCl}_{3} / \mathrm{H}_{2} \mathrm{O}\right)$ reaction mixture, the major product in the aqueous phase was the triethyl dihydroxyphosphonoacetate $\mathbf{3 1}$, the hydrate of triethyl oxophosphonoacetate.

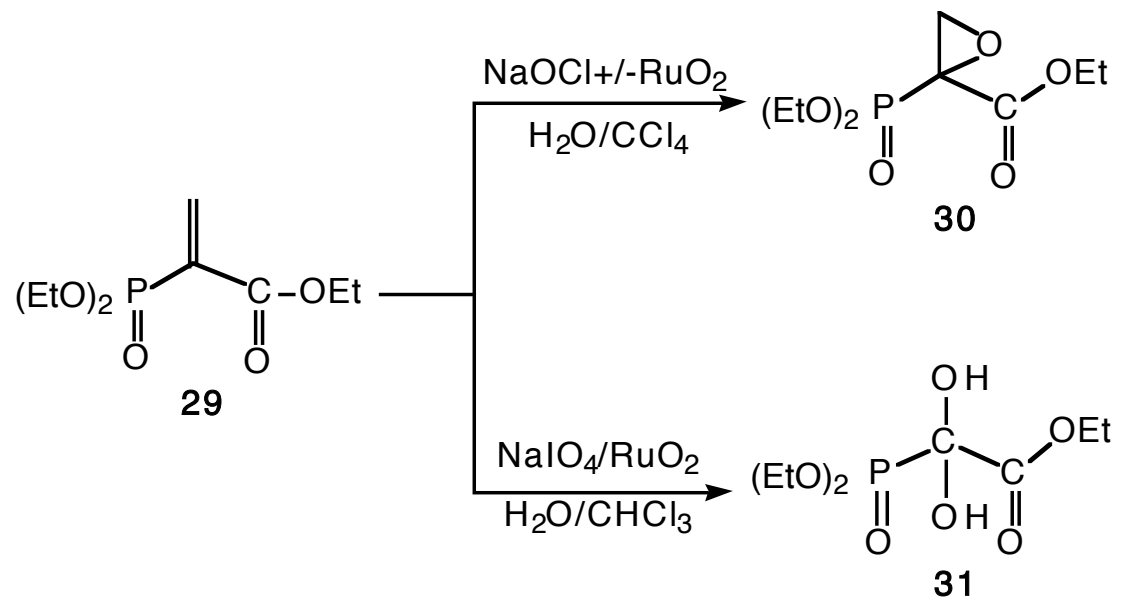

\section{Scheme 11}

$\boldsymbol{d l}$-Triethyl $\boldsymbol{\alpha}$-phosphonoacrylate oxide ${ }^{52}$ : A 11 flask was charged with $\mathrm{CCl}_{4}$ (altenatively, $\left.\mathrm{CHCl}_{3}\right)(250 \mathrm{ml})$ and $5.25 \%$ sodium hypochlorite solution $(400 \mathrm{ml} ; 282 \mathrm{mmol}) . \mathrm{RuO}_{2}(11 \mathrm{mg} ; 0.08 \mathrm{mmol})$ was added, and observed to immediately oxidize to $\mathrm{RuO}_{4}$ (yellow organic phase). A small portion of triethyl $\alpha$-phosphonoacrylate was added with vigorous shaking, causing the color of the reaction mixture to change 
briefly to black; when the mixture again became yellow, more alkene was added in the same manner. After 10 min, addition of alkene was complete $(10 \mathrm{~g} ; 42 \mathrm{mmol})$ and the two phases were separated. The organic layer was treated with isopropanol $(1 \mathrm{ml})$, then filtered through Celite, dried $\left(\mathrm{MgSO}_{4}\right)$, re-filtered, and evaporated under reduced pressure. The pale brown, oily residue was distilled under reduced pressure to give $7.49 \mathrm{~g}(71 \%)$ of the product as a colorless oil, b.p. $92-94^{\circ} \mathrm{C}(0.002 \mathrm{~mm})$.

In the steroid field, ${ }^{53}$ bromohydroxylation of the vinylphosphonate derived from cholestanone was carried out with bromine in aqueous acetic acid to afford a mixture of products containing the desired bromohydrin, which was converted to the epoxide by further treatment with $\mathrm{MeONa}$ in $\mathrm{MeOH}$.

One ingenious procedure for the construction of a nucleoside epoxyphosphonate from a 1,2-dihydroxyalkylphosphonate exploits the properties of triflates, which serve as a good leaving groups (Scheme 12).54 Treatment of 1,2-diol 32 with trifluoromethanesulfonyl chloride (TfCl) and 4-dimethylaminopyridine (DMAP) directly affords the epoxide 33 in $31 \%$ yield via displacement of an intermediate 2'-triflate unfortunately accompanied by formation of a significant by-product identified as a methylated uracil derivative 34 . When the hydroxyphosphonate was treated with trifluoromethanesulfonyl chloride and 4pyrrolidinopyridine (4-PDP) in $\mathrm{CH}_{2} \mathrm{Cl}_{2}$ at $0^{\circ} \mathrm{C}$, the nucleoside epoxyphosphonate 33 was obtained in $74 \%$ yield, and no alkylated by-products were detected. The trityl group was removed by treatment of $\mathbf{3 3}$ with acetic acid in water, providing the final target 1-(2,3anhydro-3-(diethoxyphosphinyl)- $\beta$-D-lyxofuranosyl)uracil 35 in $88 \%$ yield. The same strategy could also be used to prepare the isomeric 2',3'-epoxy-2'-phosphono derivative.

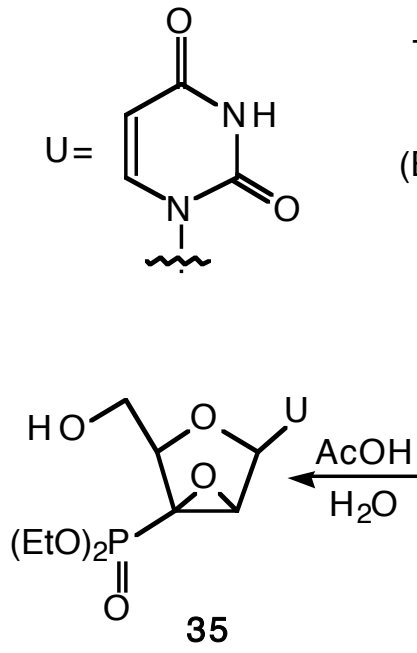

35<smiles>CCOCC1OC(Cl)C(O)C1(O)P(=O)(O)O</smiles><smiles>CCOCC1OC2(O)C3C2C13[PH](=O)OCC</smiles>

33

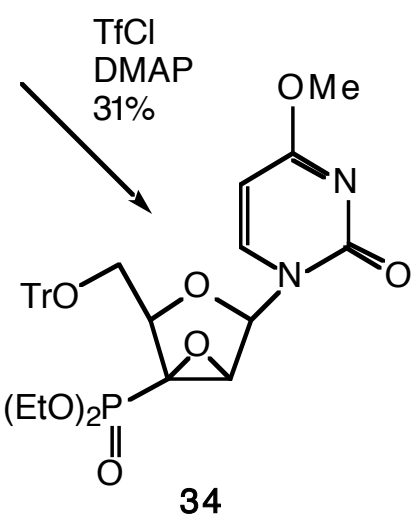

34

\section{Scheme 12}

1-[2,3-Anhydro-3-(diethoxyphosphinyl)-5- $O$-trityl- $\beta$-D-lyxofuranosyl] uracil $^{54}$ : To an ice cold solution of compound 32 (146 mg, $0.23 \mathrm{mmol}$ ) and 4-pyrrolidinopyridine (4-PDP, $210 \mathrm{mg}, 1.42 \mathrm{mmol})$ in $\mathrm{CH}_{2} \mathrm{Cl}_{2}(4 \mathrm{ml})$ was added dropwise triflyl chloride $(30 \mu \mathrm{l}, 0.28 \mathrm{mmol})$ under $\mathrm{N}_{2}$. The reaction mixture was allowed to warm to r.t. over $1 \mathrm{~h}$ with stirring, and then poured into water $(20 \mathrm{ml})$. After separation of the layers, the water phase was extracted with $\mathrm{CH}_{2} \mathrm{Cl}_{2}(15 \mathrm{ml} \times 3)$, and the combined organic phase was washed with brine $(20 \mathrm{ml} \times 2)$, and water $\left(20 \mathrm{ml}\right.$ x 2) and then dried over $\mathrm{Na}_{2} \mathrm{SO}_{4}$. The solvent was removed under reduced pressure and the residue was purified by radial chromatography $\left(\mathrm{CHCl}_{3}: \mathrm{MeOH}, 95: 5\right)$ to give the title compound (105 $\left.\mathrm{mg}, 74 \%\right)$. 


\subsection{The direct epoxidation of $\alpha, \beta$-unsaturated phosphonates}

The most attractive and potentially most general route for the synthesis of dialkyl 1,2-epoxyalkylphosphonates and its various $\alpha$ - and $\beta$-substituted analogs 6 appears to be the direct epoxidation of the corresponding dialkyl vinylphosphonates 36 (Scheme 13). The syntheses of dialkyl vinyphosphonates with essentially any desired combination of $\alpha$ and $\beta$ substituents can be achieved readily by a number of procedures. ${ }^{55}$ The use of vinylphosphonates offers appreciable advantages. Not only are the two isomeric unsaturated phosphonates formed when $\mathrm{R}^{2}$ or $\mathrm{R}^{3} \neq \mathrm{H}$ readily separable prior to cis- or trans-epoxidation of the appropriate isomer, but the use of these unsaturated intermediates permits an acidcatalyzed hydrolysis of the ester functions prior to epoxidation.<smiles>[R7]C([R])=C([R7])P(=O)([18OH])[18OH]</smiles>

\section{Scheme 13}

In view of the relative weak electrophilicity of the double bond of vinylphosphonates and the tendencies of these compounds to undergo nucleophilic addition (Michael addition), epoxidations with either strongly electrophilic peracids or nucleophilic oxidants (akaline hydrogen peroxide and $t$-butylhydroperoxide) were experimented. Full utilization of peracids is often handicapped by the apparition of competing side reaction resulting in addition on the double bond or opening of epoxide ring. 56 For example, when a buffered trifluoroperacetic acid solution in $\mathrm{CH}_{2} \mathrm{Cl}_{2}$ was used as oxidant, ring opening of the so formed epoxide could observed. The use of $t$-butylhydroperoxide in benzene with Triton $\mathrm{B}$ as catalyst has been shown to result in the Michael addition product of the butoxide to the olefin. ${ }^{56}$ In a further example of a $\mathrm{Mo}(\mathrm{CO})_{6}$ catalyzed reaction, $t$-butylhydroperoxide in 1,2-dichloroethane at reflux fails to react with diethyl 2-methyl- and 1-methylvinylphosphonate. ${ }^{57}$ These disadvantages were overcome when these reagents were replaced by an alkaline hydrogen peroxide solution (30\% solution) in alcohol. Alkaline hydroperoxide is recognized as the most common and perhaps most generally useful reagent for epoxidation of double bonds conjugated with electron-withdrawing groups. Although hydroperoxide has proved to be uneffective at $\mathrm{pH} 4.7$ in the oxidation of diethyl 2-methyl- and 1-methylvinylphosphonate in the presence of $\mathrm{Na}_{2} \mathrm{WO}_{4}$ at $55-60^{\circ} \mathrm{C}$ without solvent, the hydroperoxide in alcoholic solution at more basic $\mathrm{pH}$ appears to have a great synthetic utility in the epoxidation of phosphonate diesters or diacids having electron-withdrawing groups. Several oxidizing systems have been developed with success including $\mathrm{H}_{2} \mathrm{O}_{2} / \mathrm{Na}_{2} \mathrm{WO}_{4} / \mathrm{NEt}_{3} / n-\mathrm{PrOH} / \mathrm{pH}$ 5.8-5.9 / 40-55 ${ }^{\circ} \mathrm{C}$, $1 \mathrm{~h} ; 58 \mathrm{H}_{2} \mathrm{O}_{2} / \mathrm{Na}_{2} \mathrm{CO}_{3} / \mathrm{MeOH} / 15^{\circ} \mathrm{C}, 3-12 \mathrm{~h} ; 59 \mathrm{H}_{2} \mathrm{O}_{2} / \mathrm{NaOH} / \mathrm{MeOH} / \mathrm{rt}, 1 \mathrm{~h} ; 60 \mathrm{H}_{2} \mathrm{O}_{2} /$ 
$\mathrm{NaHCO}_{3} / \mathrm{EtOH} / \mathrm{rt}, 2 \mathrm{~h} .{ }^{61}$ The epoxidation of $\mathbf{2 5}$ (Scheme 10) was achieved very efficiently in $95 \% \mathrm{EtOH}$ with the use of $30 \%$ aqueous $\mathrm{H}_{2} \mathrm{O}_{2}$ and sodium bicarbonate for $2 \mathrm{~h}$ at room temperature, instead of $\mathrm{NaOCl}$, to give $\mathbf{2 6}$ as a pure product in excellent yield (93\%). ${ }^{61}$

Tetraethyl oxiranylidenebis(phosphonate) ${ }^{61}$ : A solution of tetraethyl ethenylidene-1,1-bis(phosphonate) $(1.510 \mathrm{~g}, 0.0050 \mathrm{~mol}), 30 \%$ aqueous $\mathrm{H}_{2} \mathrm{O}_{2}(1 \mathrm{ml})$, and $\mathrm{NaHCO}_{3}(0.424 \mathrm{~g})$ in $95 \% \mathrm{EtOH}(5 \mathrm{ml})$ was stirred at $\mathrm{rt}$ for $2 \mathrm{~h}$, diluted with brine, and extracted twice with $\mathrm{CH}_{2} \mathrm{Cl}_{2}$. The combined organic extracts were dried $\left(\mathrm{MgSO}_{4}\right)$ and concentrated under reduced pressure to give the title compound as a clear, colorless oil (1.472 $\mathrm{g}, 0.00465$ mol, 93\%). A sample of the oil was distilled, b.p. $=121-123^{\circ} \mathrm{C}(0.07 \mathrm{~mm} \mathrm{Hg})$.

Similarly, the dimethyl 3-oxo-1-cycloalkenylphosphonates $37(n=1,2)$ were converted to the corresponding epoxy derivatives 38 by treatment in $\mathrm{MeOH}$ with $\mathrm{H}_{2} \mathrm{O}_{2}$ in the presence of $\mathrm{Na}_{2} \mathrm{CO}_{3}$ for $3 \mathrm{~h}$ with $63 \%(\mathrm{n}=1)$ and $81 \%(\mathrm{n}=2)$ yields, respectively (Scheme 14). 59

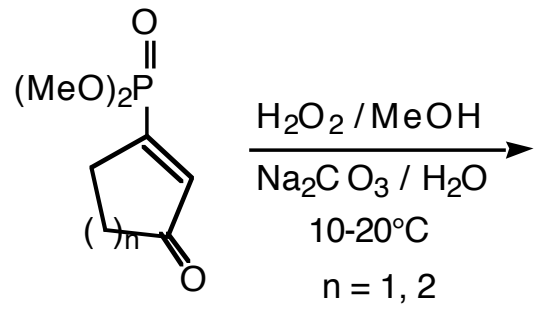

37<smiles>COP1(=O)CCCC12OC2C(=O)O</smiles>

38

Scheme 14

Dimethyl (1,2-epoxy-3-oxocyclohex-1-yl)phosphonate ${ }^{59}$ : To a solution of dimethyl (3-oxo-1-cyclohexen-1yl)phosphonate $(10 \mathrm{mmol})$ in $\mathrm{MeOH}(25 \mathrm{ml})$ are added subsequently at $10-15^{\circ} \mathrm{C}, 30 \%$ aq $\mathrm{H}_{2} \mathrm{O}_{2}(2 \mathrm{ml})$ in one portion and then dropwise a solution of $\mathrm{Na}_{2} \mathrm{CO}_{3}(500 \mathrm{mg}, 4.7 \mathrm{mmol})$ in $\mathrm{H}_{2} \mathrm{O}(10 \mathrm{ml})$. Stirring is continued at $15-$ $20^{\circ} \mathrm{C}$ until the complete consumption is confirmed by TLC. TLC probes are diluted with $\mathrm{CH}_{2} \mathrm{Cl}_{2}$ and shaken with a few drops of $\mathrm{H}_{2} \mathrm{O}$ prior placing them on the TLC plate. $\mathrm{R}_{\mathrm{f}}$ values of the products differ only slightly from the slower moving starting materials, but the epoxides are easily detected by their dark brown spots with iodine vapour. The mixture is evaporated at reduced pressure to $1 / 3$ of the volume and then partitioned between $\mathrm{H}_{2} \mathrm{O}$ (25 ml) and $\mathrm{CH}_{2} \mathrm{Cl}_{2}(50 \mathrm{ml})$. The product is extracted with $\mathrm{CH}_{2} \mathrm{Cl}_{2}(3 \mathrm{x} 40 \mathrm{ml})$ and the combined organic phases are dried $\left(\mathrm{Na}_{2} \mathrm{SO}_{4}\right)$ and evaporated under reduced pressure. The crude epoxide is purified by flash chromatography on silica gel and/or Kugelrohr distillation at 0.01 Torr (0.0135 mbar): yield $81 \%$.

Very recently, a variety of diethyl vinylphosphonates $36\left(\mathrm{R}^{1}=\mathrm{Et}\right)$ were oxidized in moderate to good yields (19-84\%) using dioxirane generated in situ from buffered monopersulfate (oxone) and a ketone in a two-phase $\left(\mathrm{CH}_{2} \mathrm{Cl}_{2} / \mathrm{H}_{2} \mathrm{O}\right)$ reaction mixture. 62 On account of the $\mathrm{pH}$ dependence of the dioxirane stability, the process needs an acurate control of the $\mathrm{pH}$ at 7.4. However, the reaction is often very sluggish, requiring regular addition of fresh portions of oxone and lengthy reaction times. 


\section{Preparations of fosfomycin}

Fosfomycin 39, formerly called phosphonomycin, is a low molecular weight antibiotic of unusual structure, which was originally isolated in 1969 from used culture medium of Streptomyces fradiae.1,63 The structure was established by NMR and IR, by MS of its dimethylester, and by direct comparison of the monobenzylammonium salt of the natural and synthetic products. ${ }^{64}$ The absolute configuration was determined chemically as $(-)(1 R, 2 S)$ (Z)-1,2-epoxypropylphosphonic acid. Fosfomycin is also produced by various species of Pseudomonas such as Pseudomonas syringae ${ }^{65}$ or Pseudomonas viridiflava. ${ }^{66}$ Fosfomycin is a broad spectrum antibiotic effective against both Gram-positive and Gram-negative infections in mammals, and its effectiveness is comparable with that of tetracycline or chloramphenicol. ${ }^{67}$ The antibiotic irreversibly inactivates the uridine-5'-diphospho-Nacetylglucosamine-3-O-enolpyruvyltransferase (MurA), the enzyme which catalyzes the first committed step in cell wall biosynthesis. ${ }^{68}$ The inactivation occurs through alkylation of a cysteine residue (Cys 115 of the enzyme from Escherichia coli) in the active site of MurA.68,69 The antibiotic, whose action has been investigated in depth ${ }^{70}$, can be administrated orally or by intravenous way and shows little toxicity to humans. Early reported works using isotope labelling techniques have shown that labelling of carbons $\mathrm{C} 1$ and $\mathrm{C} 2$ was provided by $\left[1,6-{ }^{14} \mathrm{C}\right]$ glucose, which primarily labels $\mathrm{C} 1,\left[2-{ }^{14} \mathrm{C}\right]$ glucose, which labels $\mathrm{C} 2$ and $\left[2-{ }^{14} \mathrm{C}\right]$ acetate, which labels both $\mathrm{C} 1$ and $\mathrm{C} 2$ in equal amounts. ${ }^{71}$ From these data, phosphoenolpyruvate was suggested as the most likely precursor of carbons $\mathrm{C} 1$ and $\mathrm{C} 2$ of fosfomycin. ${ }^{71}$ More recently reported works have shown that when 1,1-dideuterio-2hydroxyethylphosphonic acid is fed to Streptomyces fradiae the deuterium is incorporated into the fosfomycin derived therefrom, via phosphonoacetaldehyde. ${ }^{72}$ Fosfomycin is thought to be produced from phosphoenolpyruvate via phosphonopyruvate and phosphonoacetaldehyde through the addition of a one carbon species to the pro- $(S)$ face of the carbonyl group. ${ }^{73}$ Only the $(S)$ form of 2-hydroxy-[2-2 $\mathrm{H}_{1}$ ]ethylphosphonic acid was incorporated into the fosfomycin of Streptomyces fradiae. ${ }^{74}$ Fosfomycin is present on the pharmaceutical market as the disodium, ${ }^{75}$ calcium, ${ }^{76}$ and tris(hydroxymethyl)ammonium salts ${ }^{77}$ The structure of the diester, monoester, disodium, calcium and phenethylammonium salts of fosfomycin have been studied by ${ }^{1} \mathrm{H},{ }^{13} \mathrm{C},{ }^{31} \mathrm{P} \mathrm{NMR}$, IR and Raman spectroscopy, and X-ray crystallography. ${ }^{78}$ Presently a number of methods are available for its synthesis and we selected the more attractive ones. 
<smiles>[2H][C@@]1(P(=O)(O)O)O[C@]1([2H])[CH]</smiles>

39

\section{Figure 1}

The first racemic synthesis of fosfomycin 39 described in 1969 was based on the oxidation of the $( \pm)$ (Z)-1-propenylphosphonic acid 42 (Scheme 15).64 The reaction was effectively achieved using an excess of $\mathrm{H}_{2} \mathrm{O}_{2}\left(30 \%\right.$ solution) at $60^{\circ} \mathrm{C}$ in the presence of $\mathrm{Na}_{2} \mathrm{WO}_{4}$ as catalyst (2\%) at $\mathrm{pH}$ 5.5. The (Z)-1-propenylphosphonic acid 42 was obtained by stereospecific reduction, with Lindlar catalyst, of the dibutyl 1-propynylphosphonate $\mathbf{4 0}$ into dibutyl (Z)-1-propenylphosphonate $\mathbf{4 1}$ followed by hydrolysis with concentrated hydrochloric acid of the ester functions. Optical resolution of the racemic $( \pm)(Z)-1,2-$ epoxypropylphosphonic acid to fosfomycin was accomplished by way of the quinine salt.
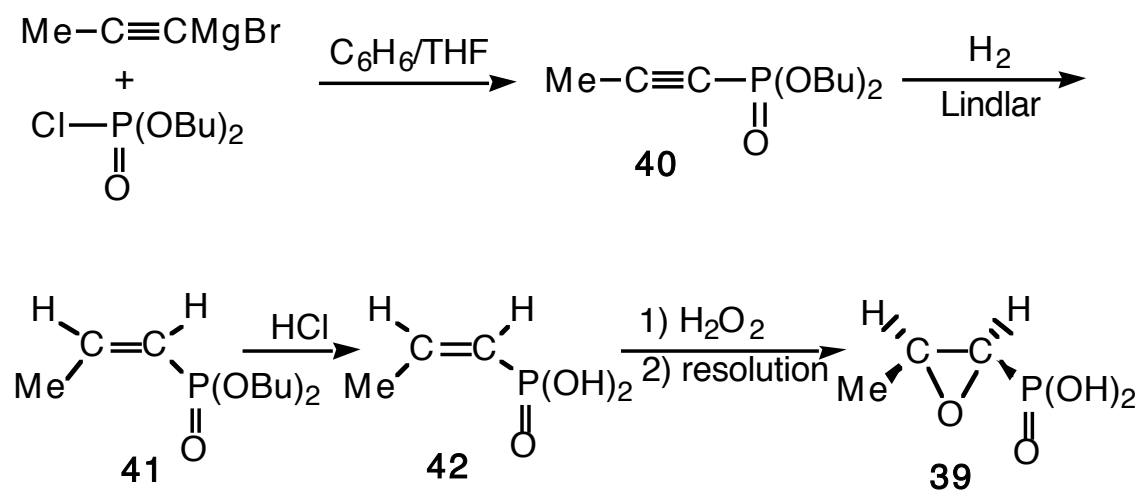

Scheme 15

Latter, the synthesis has been improved using the acid sensitive $t$-butyl alcohol as blocking group instead of $n$-butyl alcohol and propargyl alcohol instead of propyne. A sequence of reactions for the conversion of propargyl alcohol into $( \pm)(Z)$-1-propenylphosphonic acid, which proceeds in $81 \%$ overall yield via the alkadienylphosphonate has been developed (Scheme 16).58,79 After rearrangement of the alkynylphosphite into alkadienylphosphonate 43 (Boisselle and Meinhardt rearrangement), ${ }^{80}$ this one was selectively and stereospecifically hydrogenated in benzene with $\mathrm{Pd} / \mathrm{C}$, with hydrogen attacking only the terminal double bond of the allene moiety, to give the di-t-butyl (Z)-1-propenylphosphonate 44 . The rapid removal of the two $t$-butyl groups was accomplished by refluxing the benzene solution with a strong acid catalyst. An elegant procedure was to use (Z)-1-propenylphosphonic acid as catalyst to avoid contaminating the product with a foreign acid. Removal of the solvent leaves $(Z)-1$ propenylphosphonic acid $\mathbf{4 2}$ in $81 \%$ overall yield after five reactions in the same pot. Conversion of $( \pm)(Z)$-1-propenylphosphonic acid $\mathbf{4 2}$ to fosfomycin 39 was accomplished by using (+)- $\alpha$-phenethylamine as resolving base in propanol, followed by treatment at $\mathrm{pH}$ of 
5.8-5.9 with $\mathrm{H}_{2} \mathrm{O}_{2}$ in the presence of $\mathrm{Na}_{2} \mathrm{WO}_{4}$ at $50-55^{\circ} \mathrm{C}$. A single recrystallization from aqueous propanol afforded fosfomycin salt of $100 \%$ optical purity.

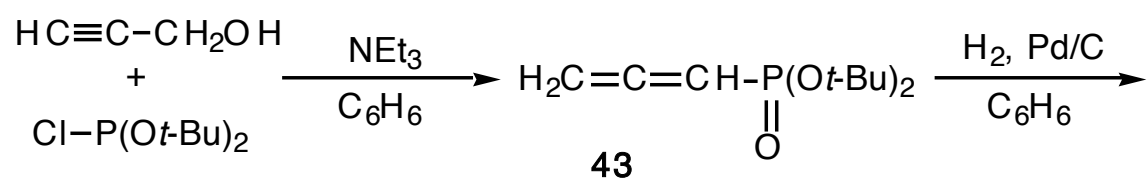

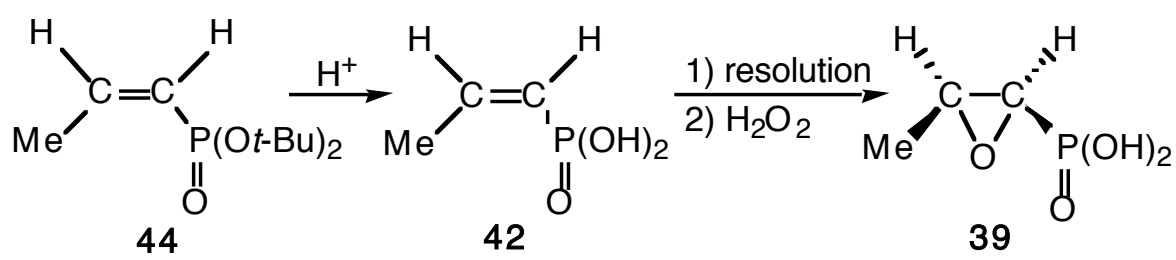

Scheme 16

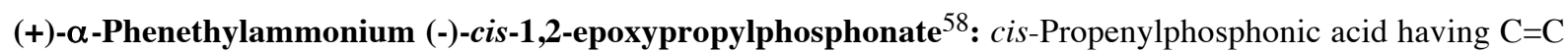
purity of $83 \%$ (148 g, $1.00 \mathrm{~mol}$ "pure") was dissolved in propanol $(800 \mathrm{ml})$. To the stirred solution was added (+)- $\alpha$-phenethylamine $(80.5 \mathrm{~g}, 0.665 \mathrm{~mol})$, followed by enough triethylamine $(56 \mathrm{~g}, 0.553 \mathrm{~mol})$ to reach a pH of 5.8-5.9. The resulting warm solution was treated in one portion with sodium tungstate dihydrate $(5.0 \mathrm{~g}, 0.015$ $\mathrm{mol})$ and disodium ethylenediaminetetraacetic acid $(1.0 \mathrm{~g})$ dissolved together in $15 \mathrm{ml}$ of warm $\left(65-70^{\circ} \mathrm{C}\right)$ water. Hydrogen peroxide $(1.53 \mathrm{~mol}, 157 \mathrm{ml}$ of a $30 \%$ solution) was then added dropwise with stirring over a $15 \mathrm{~min}$ period while maintaining the temperature between 40 and $55^{\circ} \mathrm{C}$. After the addition was complete, the reaction was kept at $50-55^{\circ} \mathrm{C}$ for $1 \mathrm{~h}$ to complete the epoxidation. The solution was then cooled to $-5^{\circ} \mathrm{C}$ over a $30 \mathrm{~min}$ period to initiate crystallization. After stirring for $2 \mathrm{~h}$ at $-5^{\circ} \mathrm{C}$, the product was filtered and the cake washed with cold propanol (four $50 \mathrm{ml}$ portions). This salt when dried weighed $106 \mathrm{~g}$, and was about $92 \%$ optically pure. To complete the resolution, the salt was dissolved in $770 \mathrm{ml}$ of hot $\left(75-80^{\circ} \mathrm{C}\right)$ propanol. The slightly turbid solution was charcoal treated $(2.5 \mathrm{~g})$ and filtered while hot throgh a preheated funnel. To the hot filtrate was added $80 \mathrm{ml}$ of warm $\left(60-70^{\circ} \mathrm{C}\right)$ water. Crystallization of the monohydrate began within a few minutes. After stirring the mixture at $0^{\circ} \mathrm{C}$ for $2 \mathrm{~h}$ the product was filtered, washed with cold propanol (three $25 \mathrm{ml}$ portions), and dried in vacuo at $45^{\circ} \mathrm{C}$. The yield of phosphonomycin salt was $90.1 \mathrm{~g}(32.5 \%)$ : m.p. $132-134^{\circ} \mathrm{C}$ (dec.).

An alternative synthesis of fosfomycin 39 has also been realized by the halohydrin route. ${ }^{81}$ Treatment of $( \pm)(Z)$-1-propenylphosphonic acid 42 in aqueous solution with $t$-butyl- or sodium hypochlorite afforded threo-1-chloro-2-hydroxypropylphosphonic acid (85\%). Resolution was accomplished with (-) $\alpha$-phenylethylamine to yield (+)-chlorohydrin (80\%), which was converted to (-) fosfomycin 39 (85-90\%) in $10 \mathrm{M}$ aqueous sodium hydroxide.

With the aim in view to cover the access to fosfomycin, several important and attractive synthetic methods were reported in patents. They include, for example, precursors such as dimethyl hydroxymethylphosphonate, 82 dimethyl, dibenzyl, and diallyl formylphosphonate, 83 trimethylphosphite and 2-cyano-1-hydroxypropene, ${ }^{84}$ trialkylphosphite and 2chloropropionaldehyde or 2-acetoxypropionaldehyde, 85 diethyl chloromethylphosphonate, ${ }^{11}$ dibenzylphosphite and 1-chloro-1,2-propylene oxide, ${ }^{86}$ propynylphosphonic acid, ${ }^{87}$ propenylphosphonic acid, 88 2-chloro-(cis-1,2-epoxypropyl)phosphonic acid, 89 and extrusion reactions upon thermolysis. ${ }^{90}$ The resolution of racemic acids has also been reported.$^{91}$

The first nonmicrobial asymmetric synthesis of fosfomycin 39 was based on the use of tartaric acid as a chiral auxiliary in directing an appropriate bifunctionalization of prochiral 
(Z)-1-propenylphosphonic acid (Scheme 17). ${ }^{50}$ Thus, the reaction of (2S,3S)-tartaric acid derivatives with (Z)-1-propenylphosphonic dichloride ${ }^{113}$ in $\mathrm{CH}_{2} \mathrm{Cl}_{2}$ at $-10^{\circ} \mathrm{C}$ gave rise to the cyclic phosphonates that after ring opening and crystallization afforded the monoesters (70\%). The bromohydroxylation, carried out in water at $15^{\circ} \mathrm{C}$ under neutral or acidic conditions with $\mathrm{N}$-bromoacetamide (NBA) is highly chemoselective, regiospecific and stereospecific providing threo-bromohydrins $(1 R, 2 S)$ and $(1 S, 2 R)$ in a 70:30 ratio with yields higher than $90 \%$. Crystallization of the mixture of diastereomeric bromohydrins provided the preferred $(1 R, 2 S)$ in diastereomerically pure form. After elimination of tartaric acid, the threobromohydrin was easily converted to fosfomycin as the sodium salt $\mathbf{5 0}$ by reaction with $\mathrm{MeONa}$ in $\mathrm{MeOH}$ at $40^{\circ} \mathrm{C}$ for $3 \mathrm{~h}$.

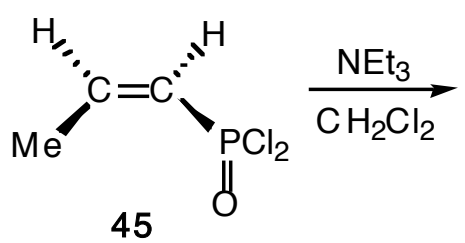

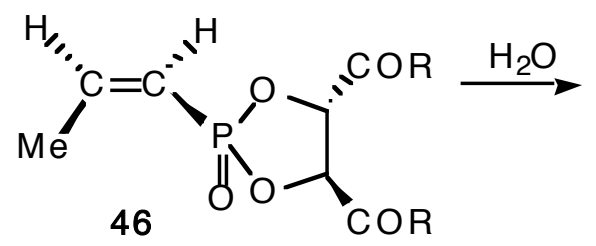

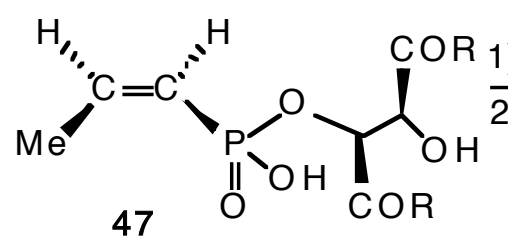

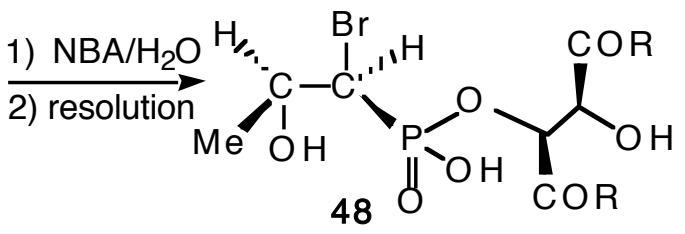

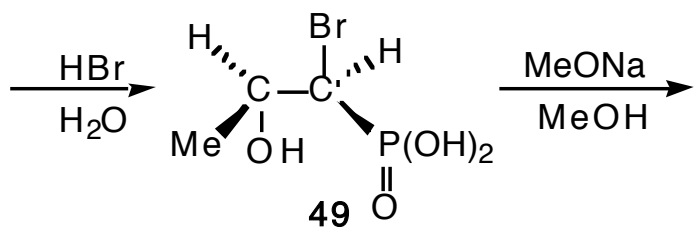<smiles>C[C@@H]1O[C@H]1[P+]([O-])O[Na]</smiles>

Scheme 17

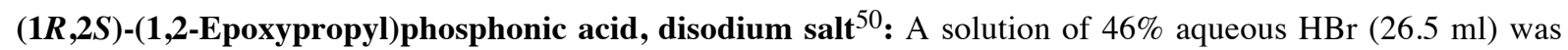
added to a solution of $\mathbf{4 8}(5.69 \mathrm{~g}, 13.12 \mathrm{mmol})$ in water $(26.5 \mathrm{ml})$. The solution was kept at $100^{\circ} \mathrm{C}$ for $16 \mathrm{~h}$. The solvent was removed by distillation under reduced pressure. Ethyl acetate $(285 \mathrm{ml})$ was added and the mixture was kept at reflux for $2 \mathrm{~h}$, cooled to ambient temperature, and filtered. Evaporation of the solvent under reduced pressure gave a residue that was added to acetone. The precipitate was filtered off. Evaporation of the solvent under reduced pressure gave crude containing (1-bromo-2-hydroxypropyl)phosphonic acid 49 and tartaric acid. The crude 49, thus obtained, was dissolved in methanol $(50 \mathrm{ml})$ and the solution was added dropwise at $40^{\circ} \mathrm{C}$ under nitrogen to a solution of sodium methoxide in methanol $(5.55 \mathrm{M}$, ca. $15 \mathrm{ml})$, in such a way as to maintain the $\mathrm{pH}$ at $12.5-13$. At complete conversion of $\mathbf{4 9}$, the reaction mixture was cooled to ambient temperature and filtered. The $\mathrm{pH}$ of the solution was brought to $\mathrm{pH} 9-10$ with methanesulfonic acid. The mixture was concentrated under reduced pressure to half volume and filtered. Evaporation of the solvent under reduced pressure gave a residue $(3.38 \mathrm{~g})$ containing $63 \% \mathrm{w} / \mathrm{w}$ of the title compound $(2.13 \mathrm{~g}, 11.7 \mathrm{mmol})$ as determined by HPLC. The residue was dissolved in methanol $(18 \mathrm{ml})$ and added, under stirring at ambient temperature, to 2propanol $(90 \mathrm{ml})$. Methanesulfonic acid $(2.5 \mathrm{~g}, 26 \mathrm{mmol})$ was added to the suspension at $15^{\circ} \mathrm{C}$. The mixture was kept at $15^{\circ} \mathrm{C}$ for $15 \mathrm{~min}$ and filtered. The solution was added at $15^{\circ} \mathrm{C}$ to a solution of sodium methoxide in methanol $(5.55 \mathrm{M}, 4.32 \mathrm{ml})$ and kept at $15^{\circ} \mathrm{C}$ for $2 \mathrm{~h}$. The precipitate was filtered and dried at $50^{\circ} \mathrm{C}$ under reduced pressure to yield $(1 R, 2 S)$-(1,2-epoxypropyl)phosphonic acid, disodium salt $\mathbf{5 0}(1.91 \mathrm{~g}, 10.5 \mathrm{mmol})$. 
Recently the conditions for a large scale synthesis of fosfomycin 39 based on the enantioselective formation of the $(1 R, 2 S)$ threo-bromohydrin by enantioselective hydrogenation of prochiral $\beta$-ketophosphonates have been described (Scheme 18). ${ }^{92}$ The starting racemic dimethyl $\alpha$-bromo- $\beta$-ketophosphonate 51 was prepared by the reaction of dimethyl 2-oxopropylphosphonate with hydrogen bromide $(8.8 \mathrm{M})$ and $\mathrm{H}_{2} \mathrm{O}_{2}(30 \%)$ in $\mathrm{THF}$ at $25^{\circ} \mathrm{C}$. Hydrogenation of a racemic $\alpha$-substituted- $\beta$-ketophosphonate usually gives four possible stereoisomers. The lability of the $\alpha$-stereogenic center allows for the stereoselective synthesis of a single isomer via dynamic kinetic resolution utilizing in situ stereoinversion. The stereoinversion to hydrogenation of racemic $\alpha$-bromo- $\beta$-ketophosphonate $\mathbf{5 1}$ depends on the determination of suitable stereochemical and kinetic parameters by computer-aided analysis of experimental conditions. In this way, the (S)-BINAP-Ru(II) complex formed in situ by simple heating of a mixture of $\left[\mathrm{RuCl}_{2} \text { (benzene) }\right]_{2}$ and $(S)$-BINAP in DMF acts as an excellent catalyst for the enantioselective hydrogenation of prochiral $\mathbf{5 1}$, leading to the dimethyl $(1 R, 2 S)$-1-bromo-2-hydroxypropyl-phosphonate $\mathbf{5 2}$ in $98 \%$ ee and $84 \%$ yield. The reaction takes place smoothly in $\mathrm{MeOH}$ under 4 atm at $25^{\circ} \mathrm{C}$ during $100 \mathrm{~h}$. With these conditions, a partial (15\%) hydrogenolytic debromination was observed, which can be completely achieved using $\mathrm{Pd} / \mathrm{CaCO}_{3}-90 \% \mathrm{MeOH}$. The fosfomycin, as the sodium salt 50, can be obtained by acid-catalyzed hydrolysis of the hydrogenation product, followed by treatment with sodium hydroxide.<smiles>CC(=O)C(Br)[PH](C)=O</smiles>

( \pm ) 51

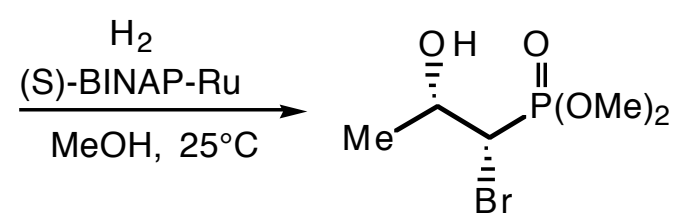

(1R, 2S) 52

Scheme 18

Another recent asymmetric synthesis of fosfomycin was based on the formation of a protected 1,2-dihydroxyphosphonate by stereoselective addition of trimethylsilyl-dibenzylphosphite $\mathbf{5 4}$ to the $(S)$-triisopropylsilyloxylactaldehyde $\mathbf{5 3}$ at low temperature (Scheme 19). ${ }^{93}$ The crude reaction mixture afforded the protected $\alpha$-hydroxyphosphonates $\mathbf{5 5}$, which on reaction with methanesulfonyl chloride followed by flash chromatography gave the methanesulfonate $\mathbf{5 6}$. The latter was treated with TBAF in THF with the aim to simultaneously deprotect the hydroxy group and to achieve the ring closure to give $\mathbf{5 7}$ as a single diastereoisomer (77\%). After deprotection at phosphorus, fosfomycin was isolated as the sodium salt $\mathbf{5 0}$ in $\mathbf{7 6 \%}$ yield. 


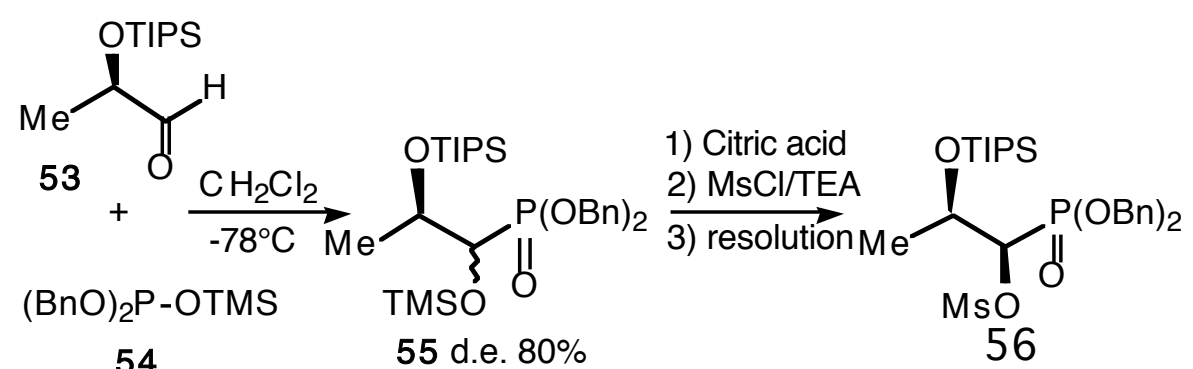

54

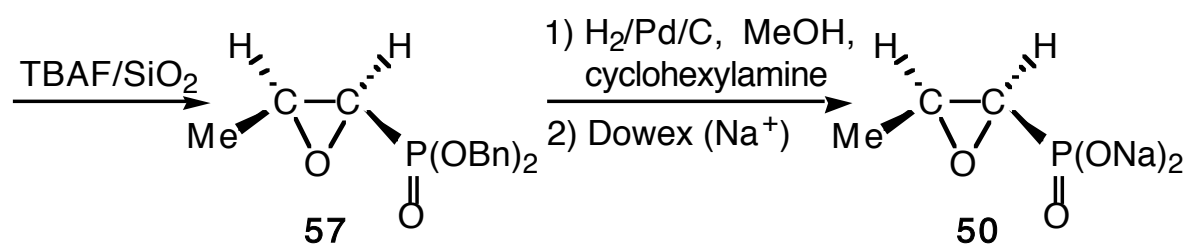

Scheme 19

The oxidation of ( $Z$ )-propenylphosphonic acid $\mathbf{4 2}$ to fosfomycin 39 by a fermentation process has also been investigated. ${ }^{94}$ Thus, it has been demonstrated that Penicillium spinolusum may be effectively employed to transform the biologically inactive $(Z)$-propenylphosphonic acid 42 into biologically active fosfomycin 39. At optimum levels of glucose, used as the carbon source, an epoxidation efficiency in olefin approaching $90 \%$ was obtained after 10 days of incubation at $28^{\circ} \mathrm{C}$ and at $\mathrm{pH}$ 5.6. It is not known if this reaction is involved in the biosynthesis of the antibiotic by Streptomyces. Moreover, the epoxidizing systems show substrate specificity since $(E)$-propenylphosphonic acid was not epoxidized.

\section{Rearrangements of 1,2-epoxyalkylphosphonates}

A variety of skeletal rearrangements of organophosphorus compounds involving migration of a phosphorus substituent are well established reactions. The ability of a phosphorus substituent to migrate from carbon to oxygen, ${ }^{95}$ oxygen to carbon, $, 80,96$ carbon to nitrogen, ${ }^{97}$ nitrogen to carbon ${ }^{98}$ and nitrogen to oxygen ${ }^{99}$ has been reported by several workers. The first example of thermal and acid-catalyzed shifts from carbon to carbon was reported in $1966 .{ }^{13} \mathrm{It}$ has been reported that diethyl 2,2-disubstituted-1,2-epoxyethylphosphonates 58 readily undergo specific rearrangement to yield, as a result of the phosphoryl group migration, diethyl 1,1-disubstituted-1-formylmethylphosphonate 59 (Scheme 20). The thermal specificity and hence applicability was limited to those substrates, which can rearrange at a temperature not exceeding $170^{\circ} \mathrm{C}(0.7 \mathrm{~mm})$ and evidence for an efficient reaction was obtained in only one instance. ${ }^{13}$ In other cases, the rearranged products were frequently unstable at the temperature $\left(270-300^{\circ} \mathrm{C}, 0.6-0.7 \mathrm{~mm}\right)$ required for rearrangement and only the dephosphorylated aldehydes were isolated accompanied by polymeric material. 
<smiles>[R7]C1([R7])OC1(P=O)[PH](=O)OCC</smiles>

58<smiles>[R7]C([R7])(C=O)P([R])(=O)OCC</smiles>

59

\section{Scheme 20}

The thermal technique has largely been supplanted in recent years by the use of Lewis acids, which are much more generally useful in this reaction. ${ }^{13,14,17,56 a, 100-103}$ The preferred catalyst for this reaction was found to be boron trifluoride etherate $\left(\mathrm{BF}_{3} \cdot \mathrm{Et}_{2} \mathrm{O}\right)$. Its use increases reaction rates and yields. Rearrangement of readily available diethyl 2,2disubstituted-1,2-epoxyethylphosphonates $\mathbf{5 8}$ to diethyl 1,1-disubstituted-1formylmethylphosphonates $\mathbf{5 9}$ can be effected on large scale in benzene or $\mathrm{CH}_{2} \mathrm{Cl}_{2}$ at room temperature in few minutes. In every instance, only the carbonyl compound was isolated. It necessarely involved formation of a carbonium ion $\mathbf{6 0}$ and migration of the phosphoryl group rather than the hydrogen atom to the carbonium ion. The boron trifluoride-catalyzed rearragement of $\beta$-disubstituted epoxyphosphonates constitutes an expeditious route for the synthesis of diethyl 1-formylalkylphosphonates (Scheme 21), 102 and a large variety of 1,1disubstituted phosphonoacetaldehydes have been synthesized on preparative scale and in excellent yields from symmetrical or unsymmetrical ketones as outlined in Table 4. The preferred catalyst for this rearrangement was found to be $\mathrm{BF}_{3} \cdot \mathrm{Et}_{2} \mathrm{O}$ since diethyl 2,2disubstituted-1,2-epoxymethylphosphonates $\mathbf{5 8}$ on treatment with other Lewis acids such as $\mathrm{SnCl}_{4}, \mathrm{SnBr}_{2}, \mathrm{ZnCl}_{2}, \mathrm{ZnBr}_{2}$, or $\mathrm{TaF}_{5}$ in $\mathrm{C}_{6} \mathrm{H}_{6}$ or $\mathrm{CH}_{2} \mathrm{Cl}_{2}$ gave mixture of products in which 59 was the major compound.

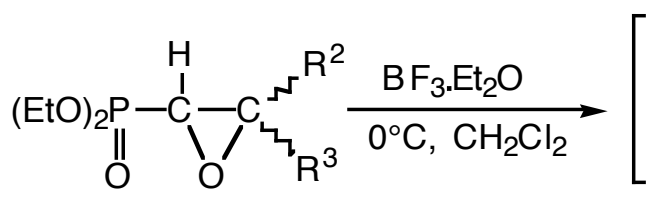

58

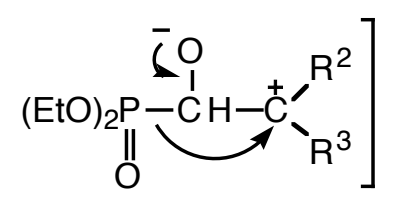

60

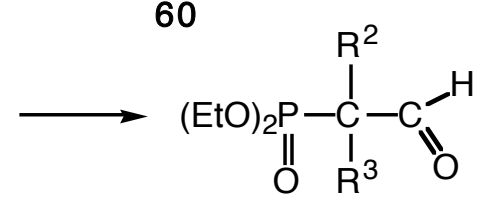

59

\section{Scheme 21}

O,O-Diethyl 1-formyl-1-methyl-1-cyclopropylmethylphosphonate ${ }^{102}$ : To the O,O-diethyl-2-cyclopropyl-1,2epoxyethylphosphonate $(11.7 \mathrm{~g} ; 0.05 \mathrm{~mol})$ in $\mathrm{CH}_{2} \mathrm{Cl}_{2}(200 \mathrm{ml})$ cooled at $0^{\circ} \mathrm{C}$ under an atmosphere of nitrogen is added $\mathrm{BF}_{3} \cdot \mathrm{Et}_{2} \mathrm{O}(3.6 \mathrm{~g} ; 0.025 \mathrm{~mol})$ in $\mathrm{CH}_{2} \mathrm{Cl}_{2}(50 \mathrm{ml})$. After $30 \mathrm{~min}$ at $0^{\circ} \mathrm{C}$ the reaction mixture is kept for two hours at room temperature then tranferred in a separatory funnel and washed with an aqueous $\mathrm{NaHCO}_{3}$ solution $(3 \times 20 \mathrm{ml})$ and water $(20 \mathrm{ml})$. The organic layer is dried over sodium sulfate. After removal of the solvent under reduced pressure we obtained a colourless liquid purified by vacuum distillation: yield $72 \%$, b.p. $112-114^{\circ} \mathrm{C} / 2$ torr. 
Table 4. Synthesis of diethyl 1,1-dialkyl-1-formylmethylphosphonates

\begin{tabular}{cccc}
\hline $\mathbf{5 9}$ & $\mathrm{R}^{2}$ & $\mathrm{R}^{3}$ & Yields (\%) \\
\hline $\mathbf{a}$ & $\mathrm{Me}$ & $\mathrm{Me}$ & 76 \\
$\mathbf{b}$ & $\mathrm{Me}$ & $\mathrm{Et}$ & 78 \\
$\mathbf{c}$ & $\mathrm{Me}$ & $i-\mathrm{Pr}$ & 75 \\
$\mathbf{d}$ & $\mathrm{Me}$ & $n-\mathrm{Pr}$ & 75 \\
$\mathbf{e}$ & $\mathrm{Me}$ & $-\checkmark$ & 72 \\
$\mathbf{f}$ & $\mathrm{Me}$ & $t-\mathrm{Bu}$ & 62 \\
$\mathbf{g}$ & $\mathrm{Me}$ & $n-\mathrm{Pent}$ & 68 \\
$\mathbf{h}$ & $\mathrm{Me}$ & $\mathrm{C}_{6} \mathrm{H}_{5}$ & 68 \\
$\mathbf{i}$ & $\mathrm{Et}$ & $\mathrm{Et}$ & 78 \\
$\mathbf{j}$ & $n-\mathrm{Pr}$ & $n-\mathrm{Pr}$ & 75 \\
$\mathbf{k}$ & $i-\mathrm{Pr}$ & $i-\mathrm{Pr}$ & 76 \\
$\mathbf{l}$ & $i-\mathrm{Bu}$ & $i-\mathrm{Bu}$ & 76 \\
$\mathbf{m}$ & \multicolumn{2}{c}{$-\left(\mathrm{CH}_{2}\right)_{4}{ }^{-}$} & 25 \\
$\mathbf{n}$ & \multicolumn{2}{c}{$-\left(\mathrm{CH}_{2}\right)_{5-}^{-}$} & 61 \\
$\mathbf{0}$ & \multicolumn{2}{c}{$-\left(\mathrm{CH}_{2}\right)_{4}-\mathrm{CMe}_{2-}$} & 71 \\
$\mathbf{p}$ & \multicolumn{2}{c}{$-\left(\mathrm{CH}_{2}\right)_{6-}^{-}$} & 60 \\
\hline
\end{tabular}

However, it has been found that there were limitations in this rearrangement. For example, the 1,2-epoxyphosphonates prepared from cyclic ketones 61 (cyclopentanone, cyclohexanone, cycloheptanone, etc...) upon treatment with $\mathrm{BF}_{3} \cdot \mathrm{Et}_{2} \mathrm{O}$ undergo a competing proton migration (Scheme 22) ${ }^{102}$ and consequently give a mixture of diethyl 1,1-disubstituted-1-formylphosphonates 62 (70\%) and diethyl 1-hydroxyallylphosphonates 63 (30\%).

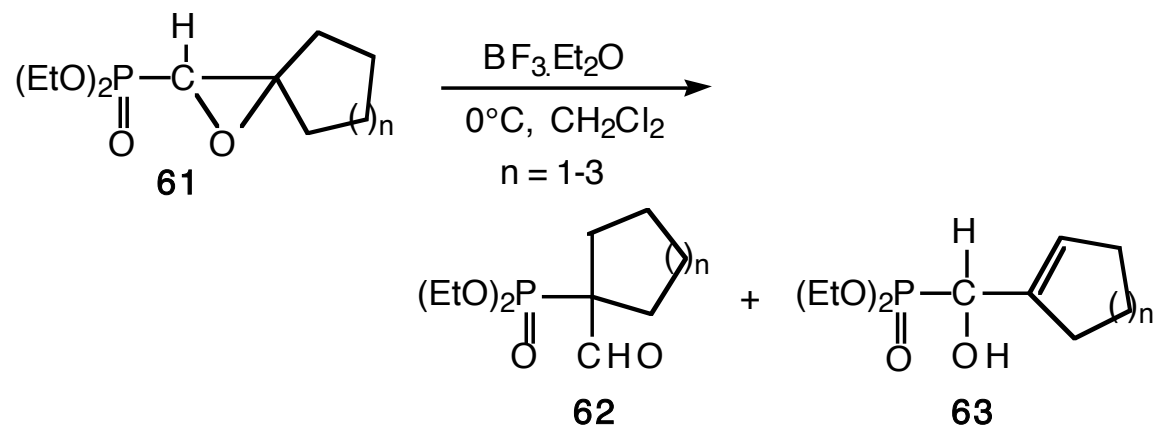

Scheme 22

The occurence of rearrangement being dependent upon the stability of the incipient carbonium ion at the $\beta$ position, the unsubstituted dialkyl 1,2-epoxyphosphonates upon treatment with $\mathrm{BF}_{3} \cdot \mathrm{Et}_{2} \mathrm{O}$ undergo ring opening without rearrangement. From the results of the 
rearrangement studies, the following order of migratory aptitudes has been established ${ }^{17}: \mathrm{p}$ anisyl $>$ p-tolyl $>$ phenyl $\geq(\mathrm{RO})_{2} \mathrm{P}(\mathrm{O})>\mathrm{H}>$ alkyl. For example, 1,2-epoxyphosphonates substituted in the $\alpha$ - and $\beta$-position with aryl groups give on treatment with $\mathrm{BF}_{3} \cdot \mathrm{Et}_{2} \mathrm{O}$ a mixture of $\alpha$ - and $\beta$-ketophosphonates.

Whereas the $\alpha$-halohydrinphosphonates were converted to 1,2-epoxyphosphonates by treatment with base, the corresponding $\beta$-halohydrinphosphonates 64 rearranged instantaneously in the presence of aqueous sodium bicarbonate and slowly in water alone to give the 1-formylethyl-phosphonic acid $\mathbf{6 5}$ (Scheme 23). ${ }^{81}$

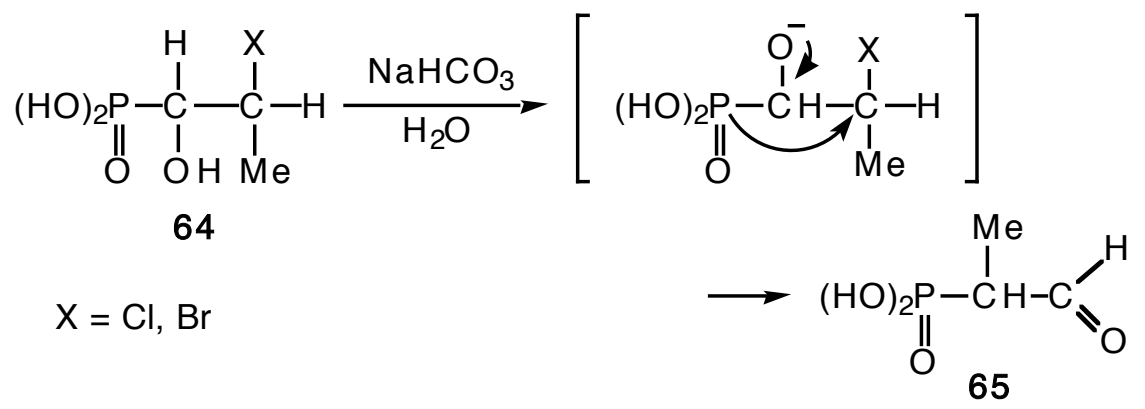

Scheme 23

\section{Reactions of 1,2-epoxyalkylphosphonates}

Most of the applications of dialkyl 1,2-epoxyalkylphosphonates are based on the ring opening reactions with nucleophiles, which provide a convenient method for incorporating functional group into the molecule. Generally, the openings of the oxirane ring are directionally specific at the $\mathrm{C} 2$ carbon and in unusual instance was evidence obtained for the formation of the isomeric products resulting from attack of nucleophile at the $\mathrm{C} 1$ carbon. Nucleophilic addition in $\alpha$ position to the phosphoryl group is generally difficult due to both steric and electronic factors. The formation of $\alpha, \beta$-difunctionalized alkylphosphonates was achieved readily by both acid-catalyzed and non-catalyzed openings of the oxirane ring. Preferred nucleophiles are water, alcohols, phenols, aqueous ammonia, amines and phosphites. Treatment of diethyl 1,2-epoxyethylphosphonate $\mathbf{2 4}$ with aqueous $\mathrm{H}_{2} \mathrm{SO}_{4}$ at reflux leads to the formation of the 1,2-dihydroxyethylphosphonate (55\%). $56 \mathrm{a}$

Diethyl 1,2-dihydroxyethylphosphonate ${ }^{56 a}$ : A solution of $3 \mathrm{~g}$ of epoxide diethyl 1,2-epoxyethylphosphonate in $25 \mathrm{ml}$ of water containing 6 drops of concentrated $\mathrm{H}_{2} \mathrm{SO}_{4}$ was refluxed for $2.5 \mathrm{~h}$, allowed to cool to room temperature, and adjusted to $\mathrm{pH} 7.0$ by addition of aqueous sodium bicarbonate. The solution was concentrated under reduced pressure to yield a thick liquid, which was extracted with $\mathrm{CHCl}_{3}$. The $\mathrm{CHCl}_{3}$ extracts were dried $\left(\mathrm{MgSO}_{4}\right)$ and concentrated to give a residue, which was distilled to yield the product. b.p. $=140^{\circ} \mathrm{C} / 0.3 \mathrm{mmHg}$, $55 \%$.

The opening of the epoxide with $\mathrm{MeOH}$ or $\mathrm{EtOH}$ containing $\mathrm{H}_{2} \mathrm{SO}_{4}$ resulted from attack of nucleophile at the $\beta$ carbon to give the two glycol monoethers, 1-hydroxy-2-methoxy or 1- 
hydroxy-2-ethoxyethylphosphonates in 55-62\% yields. ${ }^{56 a}$ However, it has been reported, and proofs were given by means of mass spectrometry, that diethyl 1-methyl-1,2epoxyethylphosphonate $\mathbf{6 c}$ under conditions of acid-catalysis $\left(\mathrm{BF}_{3} \cdot \mathrm{Et}_{2} \mathrm{O}\right.$ or $\left.\mathrm{H}_{2} \mathrm{SO}_{4}\right)$ was attacked at the $\alpha$ position by alcohols to give the diethyl 1-alkoxy-1-methyl-2hydroxyethylphosphonate. ${ }^{104}$

An attractive procedure for the preparation of phosphorylated amino alcohols from 1,2epoxyphosphonates involves the oxirane ring opening by amines. The reaction follows the general pattern of nucleophilic attack at $\mathrm{C} 2$ established with electronegative substituents at C1. The structures of reaction products demonstrate that ring opening in 1,2epoxyphosphonates $\mathbf{6 c}$ and $\mathbf{2 4}$ was directionally specific and results of attack at C2 by ammonia or amines. Analysis of the isolated products failed to produce any information for production of isomers resulting from attack at $\mathrm{C} 1$. Thus, the 1-hydroxy-2aminoethylphosphonic acids $\mathbf{6 6}$ were obtained by reaction of diethyl 1,2epoxyethylphosphonate $\mathbf{2 4}$ or diethyl 1-methyl-1,2-epoxyethylphosphonate $\mathbf{6 c}$ with aqueous ammonia at $0^{\circ} \mathrm{C}$ for $24 \mathrm{~h}$ or amines at room temperature for $48 \mathrm{~h}$, followed by acid hydrolysis (Scheme 24). 105 By contrast, ring opening of $\mathbf{2 4}$ with aniline was realized in $90 \%$ yield by heating at $120^{\circ} \mathrm{C}$ for $24 \mathrm{~h} .56 \mathrm{a}$<smiles>[Z8]C1(P(=O)(OCC)OCC)CO1</smiles>

$\mathrm{R}^{4}=\mathrm{H}, 24$

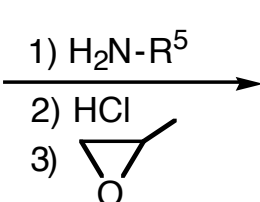

3)

$\mathrm{R}^{4}=\mathrm{Me}, 6 \mathrm{c}$

$\mathrm{R}^{5}=\mathrm{H}, \mathrm{Et}, n-\mathrm{Pr}, n-\mathrm{Bu}, i-\mathrm{Bu}, s-\mathrm{Bu}, n-\mathrm{C}_{5} \mathrm{H}_{11}, i-\mathrm{C}_{5} \mathrm{H}_{11}, n-\mathrm{C}_{6} \mathrm{H}_{13}$, $c-\mathrm{C}_{6} \mathrm{H}_{11}, n-\mathrm{C}_{7} \mathrm{H}_{15}, \mathrm{PhCH}_{2}, \mathrm{Ph}$<smiles>[Z8]C(O)(CN[Pb])P(=O)(O)O</smiles>

66

\section{Scheme 24}

1-Hydroxy-1-methyl-2-N-benzylaminoethanephosphonic acid ${ }^{105}$ : Equimolar mixture of diethyl 1,2-epoxy-1methylphosphonate and benzylamine $(0.05 \mathrm{~mol}$ scale $)$ was kept for $48 \mathrm{~h}$ at room temperature and the resulting mixture was hydrolyzed by refluxing in concentrated $\mathrm{HCl}$ for $7 \mathrm{~h}$. The solution after hydrolysis was decolorized with carbon (when necessary), evaporated to dryness and the residue was dissolved in ethanol. Treatment with propylene oxide precipitated crude product, which was purified by crystallization from water-ethanol mixtures: yield $64.8 \%$, m.p. $237-240^{\circ} \mathrm{C}$.

The reaction of tetraethyl oxiranylidene-1,1-diphosphonate $\mathbf{2 6}$ with several primary amines, including $n$-propylamine, cyclohexylamine, benzylamine and allylamine has been examined. From the reaction of $\mathbf{2 6}$ and primary amines, the phosphinyl phosphates $\mathbf{6 7}$ were isolated as the major products in 40-63\% yields (Scheme 25). ${ }^{61}$ It seems very likely that the formation of 67 was the result of a rearrangement either in concert with (path a) or subsequent to opening of the epoxide with amine and generation of an intermediate alkoxide (path b). When di- $n$ - 
propylamine was used, a second product, ethylidene-1-phosphinyl-1-phosphate, corresponding to the loss of the amine by elimination, was formed (32\%) in addition to the phosphinyl phosphate (20\%). Exposed to hydrolytic conditions at different $\mathrm{pH}(2,6,10), 26$ reacts with water very slowly. 61

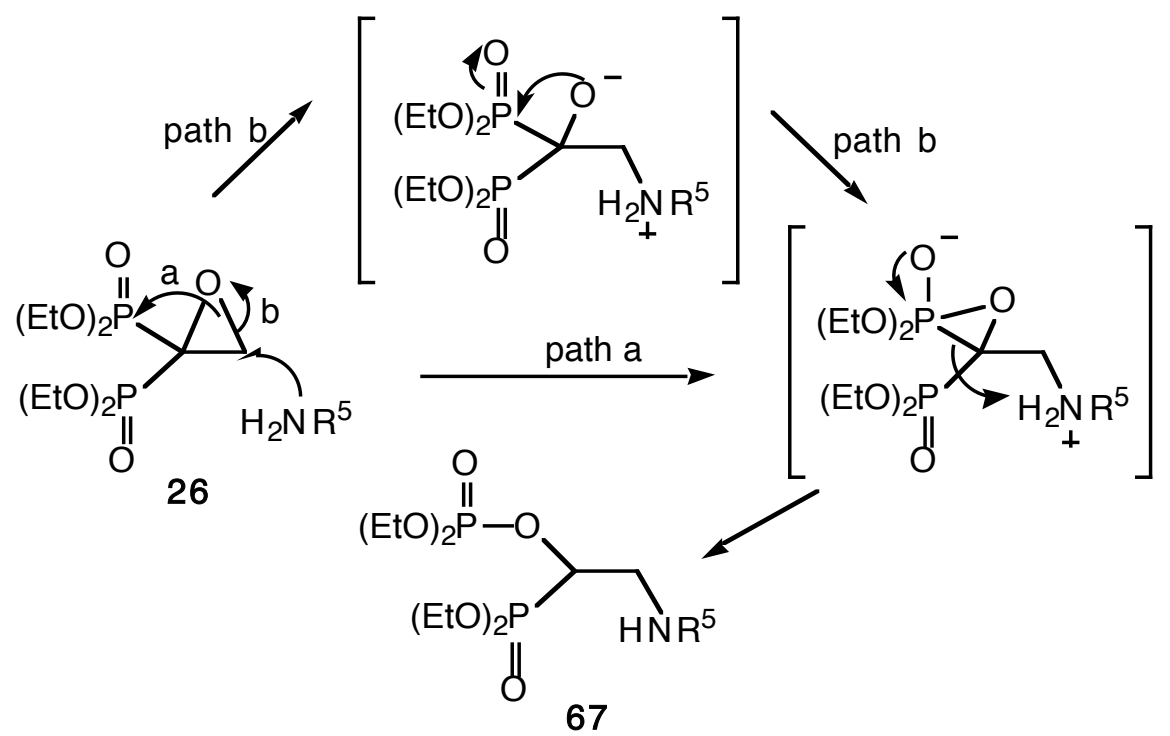

Scheme 25

Phosphoric acid, 1-(diethoxyphosphinyl)-2-(2-propen-1-ylamino)ethyl diethyl ester ${ }^{61}$ : A solution of allylamine $(2.855 \mathrm{~g}, 0.05 \mathrm{~mol})$ and tetraethyl oxiranylidenebis(phosphonate) $(3.00 \mathrm{~g}, 0.0095 \mathrm{~mol})$ in methanol $(20 \mathrm{ml})$ was cooled to $0-5^{\circ} \mathrm{C}$ by means of an ice-water bath. The mixture was stirred while the low temperature bath came to r.t. and then stirring was continued overnight at r.t. TLC ( $10 \%$ of a $10 \% \mathrm{NH}_{3} / \mathrm{CH}_{3} \mathrm{OH}$ solution in $\mathrm{CH}_{2} \mathrm{Cl}_{2}$ ) indicated that starting material was consumed. The solvent and excess of allylamine were removed in vacuo to give $3.621 \mathrm{~g}$ of crude material from which $1.025 \mathrm{~g}$ was chromatographed (flash, $160 \mathrm{~g}, 0.0403-0.063$ $\mathrm{mm}$ silica gel, $4 \mathrm{~cm}$ wide, $20-30 \%$ acetone in $\mathrm{CH}_{2} \mathrm{Cl}_{2}$ ) to give the title compound ( $0.635 \mathrm{~g}, 63 \%$ overall yield) as a clear oil.

Fosfomycin 39 on treatment with saturated aqueous ammonia for 3 days at $55-60^{\circ} \mathrm{C}$ gives as major component the (-) $(1 R, 2 R)$-(2-amino-1-hydroxypropyl)phosphonic acid $\mathbf{6 8}$ resulting from preferential attack of nucleophile at the $\mathrm{C} 2$ carbon (Scheme 26). ${ }^{72,106}$ Similarly, treatment of 39 on an acid Dowex 50 column with $0.1 \mathrm{~N} \mathrm{H}_{2} \mathrm{SO}_{4}$ delivers the corresponding diol. 72

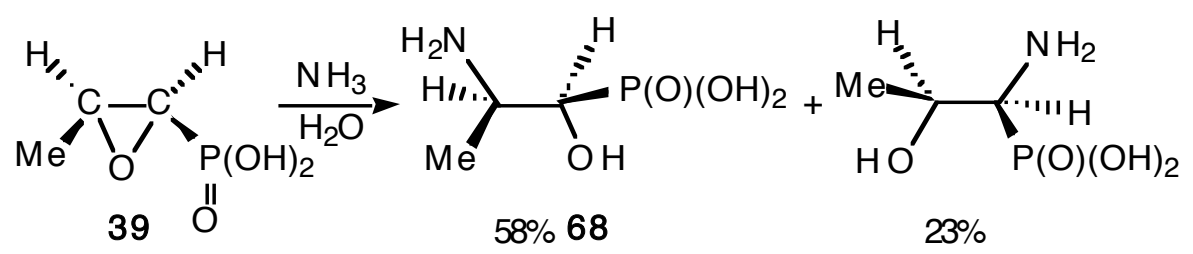

Scheme 26 
Under normal physiologic conditions, it is established that opening of fosfomycin can occur either at $\mathrm{C} 2$ or at $\mathrm{C} 1$. Thus, the inactivation of enzyme MurA by fosfomycin 39 occurs through alkylation by the thiol of a cysteine residue at $\mathrm{C} 2$ of the antibiotic in the active site of MurA. By contrast, the plasmid-mediated resistance to the antibiotic involves the reaction catalyzed by FosA ${ }^{107}$ (fosfomycin-specific metalloglutathione transferase) of fosfomycin 39 with glutathione by attack of the thiol of glutathione at $\mathrm{C} 1$ of the antibiotic. The latter addition is somewhat surprising in that nucleophilic substitutions $\alpha$ to phosphoryl are difficult. Very recently it has been shown that L-cysteine can act as an alternative thiol substrate for FosA (Scheme 27). ${ }^{108}$ The regiochemistry of the reaction was the same as that exhibited with normal substrate, glutathione, with addition of the nucleophile at the most hindered carbon, $\mathrm{C} 1$. The stereochemical course of the reaction was shown to occur with inversion of configuration at $\mathrm{C} 1$ of 39 , suggesting that the enzyme catalyzes the reaction via an $\mathrm{S}_{\mathrm{N}} 2$ or borderline $\mathrm{S}_{\mathrm{N}} 2$ mechanism.

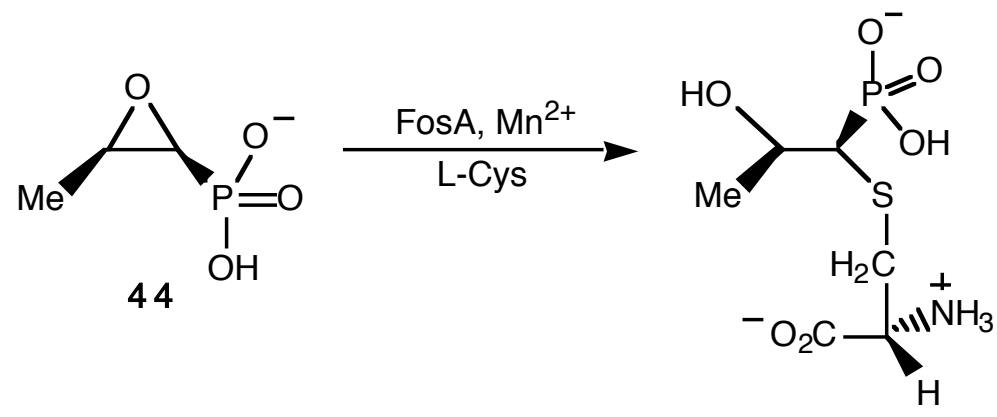

\section{Scheme 27}

Treatment of diethyl 1,2-epoxyethylphosphonate $\mathbf{2 4}$ with an alkylmagnesiumbromide failed to result in the formation of the expected hydroxyalkylphosphonate. The oxirane ring was opened by reaction with magnesium bromide to yield the halohydrin, which was hydrolyzed to the glycol during product isolation. $56 \mathrm{a}$

The readily available diethyl 1,2-epoxyalkylphosphonates 69 have proved to be valuable synthetic intermediates. On treatment with sodium dialkylphosphites in ethanolic solution they undergo a rearrangement via an oxirane opening reaction. The sodium dialkylphosphite attacks on the $\beta$ carbon atom of the epoxide ring to give unstable sodium $\alpha$ hydroxyphosphonates 70, which eliminate sodium diethylphosphite to produce the dialkyl 1formylethyl- $\left(\mathrm{R}^{4}=\mathrm{H}\right)$ or 2-oxoalkyl- $\left(\mathrm{R}^{4}=\mathrm{Me}\right)$ phosphonates 71 in $50-85 \%$ yield (Scheme 28). 109 

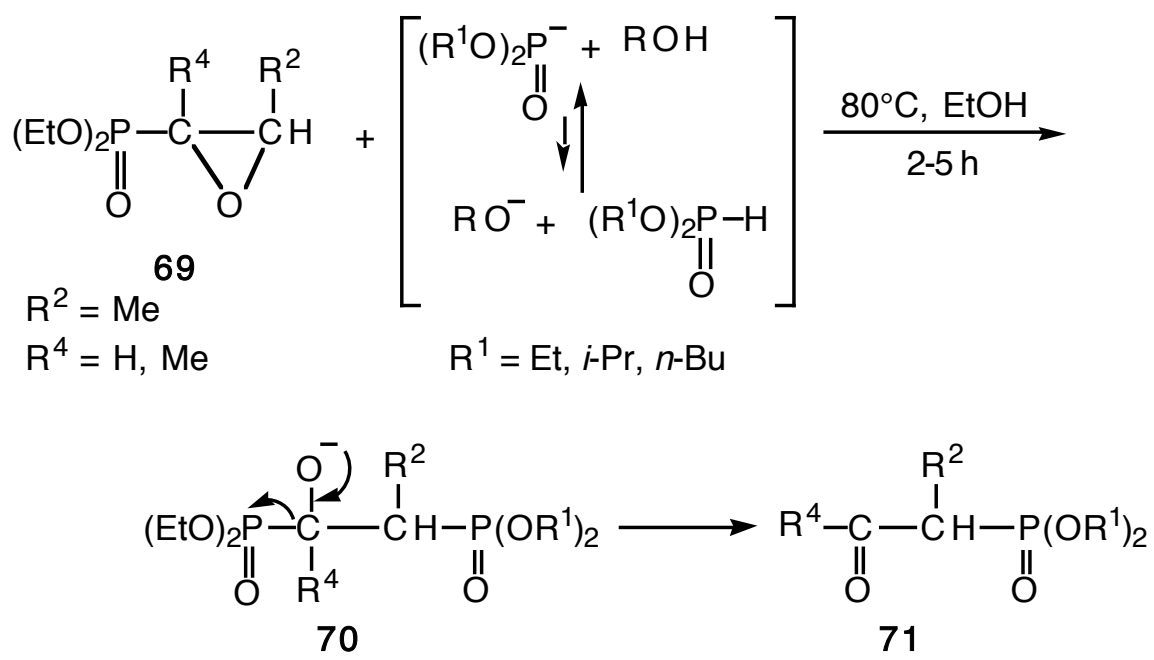

\section{Scheme 28}

Diethyl 2-oxopropylphosphonate ${ }^{109}$ : To diethyl 1,2-epoxypropanephosphonate $(19.4 \mathrm{~g}, 0.1 \mathrm{~mol})$ an ethanol solution of sodium diethyl phosphite [0.1 mol, prepared from sodium $(2.3 \mathrm{~g})$ in ethanol $(80 \mathrm{ml})]$ is added with stirring at $20^{\circ} \mathrm{C}$. After the addition is completed, the reaction mixture is heated under reflux for $2-5 \mathrm{~h}$. It is then hydrolysed by addition of water $(50 \mathrm{ml})$. The aqueous solution is extracted with chloroform, the organic phases are combined, and dried with sodium sulfate. The organic solvent is removed under reduced pressure to give an oil, which is distilled in vacuo: yield $85 \%$, b.p. $90^{\circ} \mathrm{C} / 0.1$ torr.

The diisopropyl (E)-1,2-epoxy-3-oxoalkylphosphonates 72, which were easily prepared by epoxidation of the corresponding alkenyl compounds, underwent heterocyclisation with various 1,3-bidentate nucleophiles, such as ethyl 2-pyridylacetate, 2-aminopyridine, 2-amino-

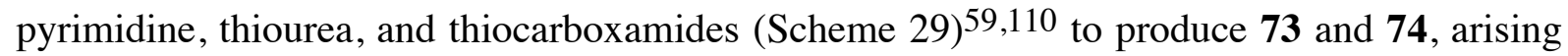
from regioselective oxirane opening and subsequent dehydration.

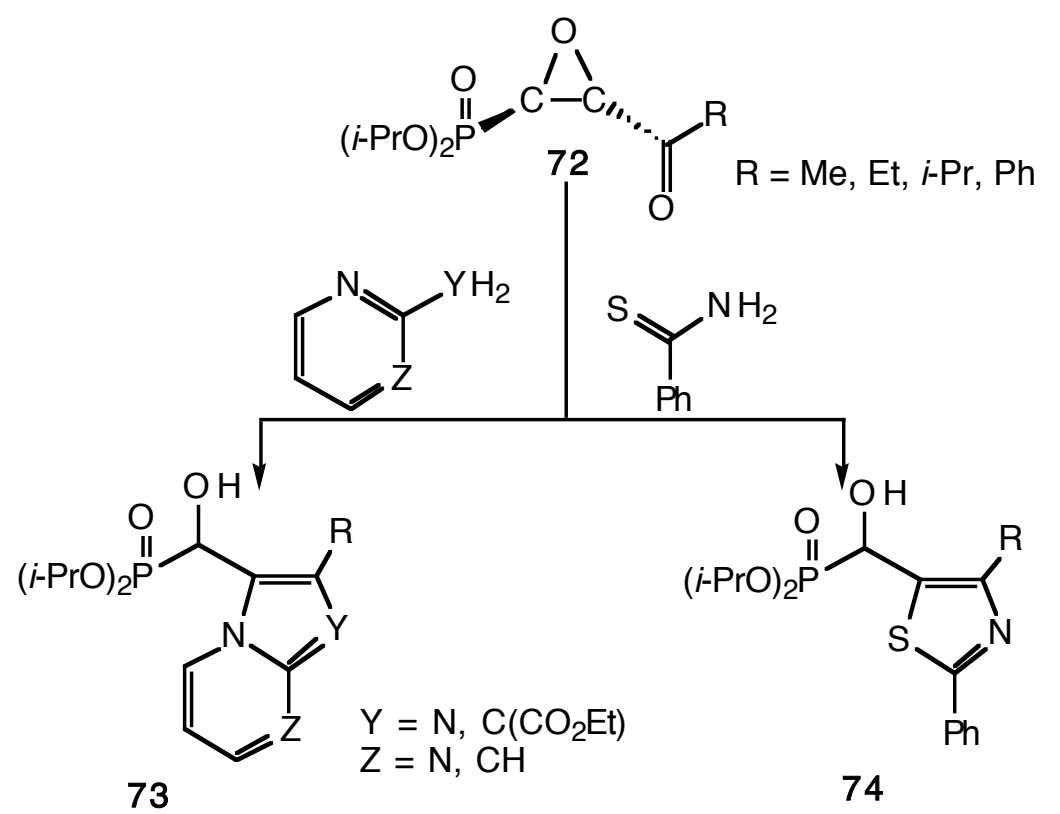

Scheme 29 
$\alpha$-Metallated 1,2-epoxyethylphosphonate ${ }^{111} \mathbf{7 5}$ can serve as precursor to higher homologues (Scheme 30). Reaction of diethyl 1,2-epoxyethylphosphonate 24 with LDA in THF at very low temperature resulted in deprotonation at the $\alpha$ position giving high yield of diethyl $\alpha$ lithioepoxy-ethylphosphonate $\mathbf{7 5}$, which can be captured under internal quench conditions by electrophiles $\mathrm{R}^{4} \mathrm{X}\left(\mathrm{R}^{4}=\mathrm{Me}_{3} \mathrm{Si}, 91 \%\right.$ and $\left.\mathrm{R}^{4}=\mathrm{Me}, 57 \%\right)$, as illustrated by the obtention of 76 .

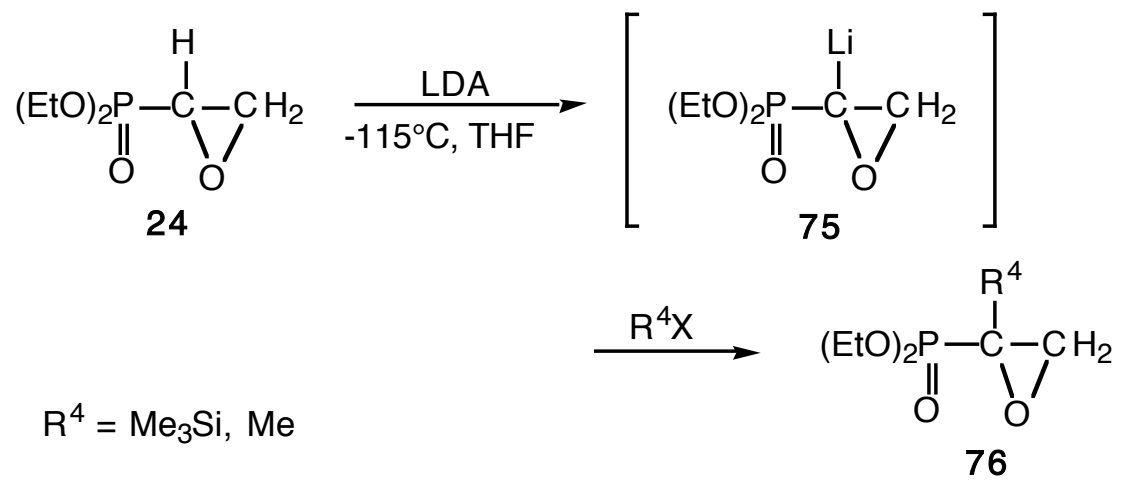

Scheme 30

Diethyl 1-trimethylsilyl-1,2-epoxyethylphosphonate ${ }^{111}$ : A solution of $1.08 \mathrm{~g}$ (6 mmol) of diethyl 1,2epoxyethylphosphonate and $1.14 \mathrm{ml}(9 \mathrm{mmol})$ of chlorotrimethylsilane dissolved in $18 \mathrm{ml}$ of THF, $4 \mathrm{ml}$ of ether and $4 \mathrm{ml}$ of hexane was cooled to $-115^{\circ} \mathrm{C}$ and then treated with $8.3 \mathrm{mmol}$ of lithium diisopropylamide in $6 \mathrm{ml}$ of THF and $5 \mathrm{ml}$ of hexane (generated from diisopropylamine $(8.3 \mathrm{mmol}$ ) and $8.3 \mathrm{mmol}$ of $n$-butyllithium in hexane) over $40 \mathrm{~min}$. After an additional $15 \mathrm{~min}$ the solution was allowed to warm to $0^{\circ} \mathrm{C}$ and then quenched with $3 \mathrm{ml}$ of water. The usual workup and the removal of volatiles under reduced pressure gave the crude trimethylsilyl derivative in $91 \%$ yield $(1.85 \mathrm{~g})$. Distillation yielded $1.72 \mathrm{~g}(84 \%)$ of title compound: b.p. $115-$ $120^{\circ} \mathrm{C}(0.1 \mathrm{~mm} \mathrm{Hg})$.

When diethyl 1-methyl-1,2-epoxyethylphosphonate $19\left(\mathrm{R}^{2}=\mathrm{R}^{3}=\mathrm{H}, \mathrm{R}^{4}=\mathrm{Me}\right)$ was subjected to the action of $n$-BuLi in excess in THF at low temperature for two hours, the 1-hydroxy-2methyl-2-hexene was obtained in $45 \%$ yield (Scheme 31). ${ }^{112}$ This reaction has been extended to a variety of 1 - or 2-substituted 1,2-epoxyphosphonates to give in each case the allylic alcohols 77 in low yields (15-32\%) as a mixture of $E$ and $Z$ isomers.

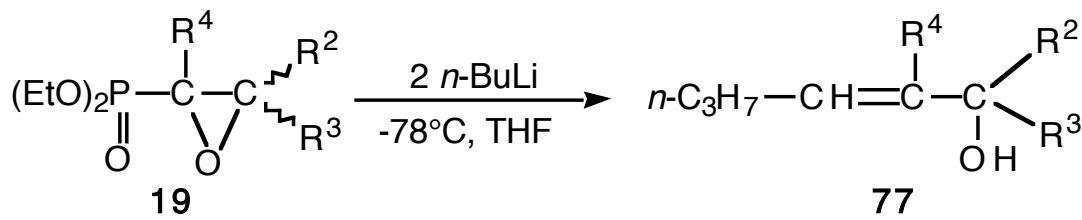

$R^{2}=R^{3}=R^{4}=H, M e$

Scheme 31

The reverse oxidation reaction of vinylphosphonates was also described. When dialkyl 1alkyl-1,2-epoxyethylphosphonates 6 were treated with an excess of thiourea in $\mathrm{MeOH}$ at reflux, dialkyl 1-alkylvinylphosphonates 79 were produced in generally good yields (Scheme $32) .42 \mathrm{c}$ 


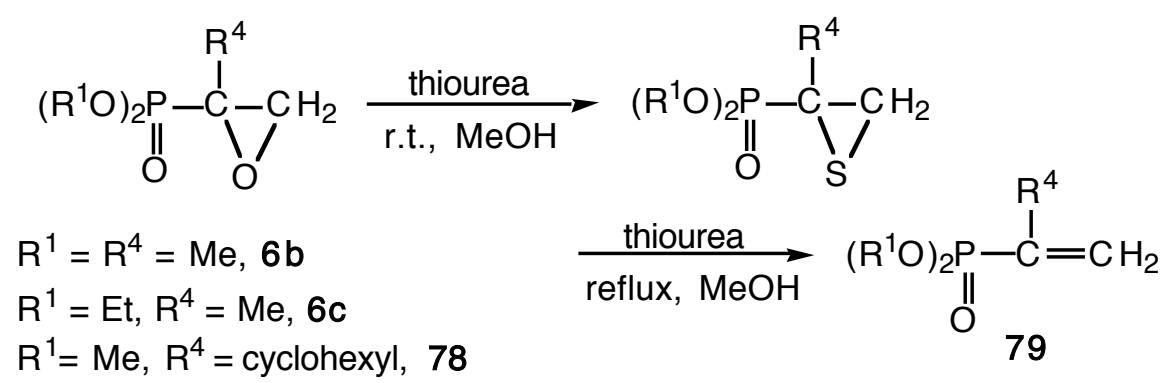

Scheme 32

\section{Conclusion}

The 1,2-epoxyalkylphosphonates constitute a valuable class of phosphorus compounds. The popularity of these molecules emanates from their simplicity, access and efficiency. The fosfomycin phenomenon has largely contributed to their popularity. Fosfomycin is still present on the pharmaceutical market owing to several drugs, ${ }^{114}$ such as Fosfocine ${ }^{\circledR}$, Monuril ${ }^{\circledR}$ and Uridoz ${ }^{\circledR}$, employed in the treatment of acute cystisis. It has induced a systematic study of epoxidation reactions, resulting in various attempts to arrive at satisfying syntheses and to extend the family. Among the four classes of reaction, which resume almost all the ways of access to 1,2-epoxyphosphonates, the halohydrins and $\alpha, \beta$ unsaturated intermediates are the most efficient precursors in terms of stereoselectivity. Undoubtedly, significant progress have been achieved. However, the efforts being largely confined to fosfomycin or analogs, most of these investigations have captured the energy of chemists to the detriment of the search of new phosphonic structures containing the epoxide moiety. The prochiral vinylphosphonates of controlled geometry being easily available, it would be interesting to develop the asymmetric functionalization of these attractive intermediates by employing both the halohydrin and peroxide approaches with chiral ester substituents at phosphorus or chiral epoxidation reagents. The exploration of new mild epoxidation processes with the aim to introduce biologically active groups would be a useful improvement. Careful investigations of $\alpha$-metallated epoxyalkyl-phosphonates may also afford some unusual compounds.

We are grateful to the Centre National de la Recherche Scientifique (CNRS) and Ecole Polytechnique for financial support to B.I.

(1) Hendlin, D.; Stapley, E. O.; Jackson, M.; Wallick, H.; Miller, A. K.; Wolf, F. J.; Miller, T. W.; Chaier, L.; Kahan, F. M.; Foltz, E. L.; Woodruff, H. B.; Mata, J. M.; Hernandez, S.; Mochales, S. Science 1969, 166, 122-123.

Chaiet, L.; Miller, T. W.; Goegelman, R. T.; Kempf, A. J.; Wolf, F. J. J. Antibiotics 1970, 23, 336-347. 
(2) Newmann, M.S.; Magerlein, B. J. Org. React. 1949, 5, 413-440.

(3) Waschbüsch, R.; Carran, J.; Marinetti, A.; Savignac, P. Synthesis 1997, 727-743.

(4) Kabachnik, M. I.; Schepeleva, E.S. Dokl. Akad. Nauk SSSR 1950, 75, 219-222; Chem. Abstr. 1951, 6569.

Kabachnik, M. I.; Medved, T. Ya. Izv. Akad. Nauk SSSR Ser. Khim. 1951, 635-640; Chem. Abstr. 1951, 8444.

Kabachnik, M.I.; Schepeleva, E.S. Izv. Akad. Nauk SSSR Ser. Khim. 1951, 185- 191;

Chem. Abstr. 1951, 10191.

Crofts, P. C.; Kosolappoff, G. M. J. Am. Chem. Soc. 1953, 75, 5738-5740.

Korshak, V. V.; Gribova, I. A.; Andreeva, M. A. Izv. Akad. Nauk SSSR Ser. Khim. 1957, 631-635; Engl. Transl. 641-646.

McConnell, R. L.; McCall, M. A.; Coover, H. W. Jr. J. Org. Chem. 1957, 22, 462465.

(5) Martynov, V. F.; Timofeev, V. E. J. Gen. Chem. USSR (Engl. Transl.) 1962, 32, 3383; Zh. Obshch. Khim. 1962, 32, 3449; Chem. Abstr. 1963, 68, 9121.

Martynov, V. F.; Timofeev, V. E. J. Gen. Chem. USSR (Engl. Transl.) 1964, 34, 3950-3952; Zh. Obshch. Khim. 1964, 34, 3890-3893; Chem. Abstr. 1965, 62, 19457.

(6) Coutrot, P.; Savignac, P. Synthesis 1978, 34-36.

(7) Lee, K.; Shin, W. S.; Oh, D. Y. Synth. Commun. 1992, 22, 649-655.

(8) Coutrot, P.; Laurenço, C.; Normant, J. F.; Perriot, P.; Savignac, P.; Villieras, J. Synthesis 1977, 615-617.

(9) Perriot, P.; Villieras, J.; Normant, J. F. Synthesis 1978, 33-34.

(10) Le Menn, J.-C.; Sarrazin, J.; Tallec, A. Can. J. Chem. 1989, 67, 1332-1343.

(11) Christensen, B. G.; Firestone, R. A. Patent (Merck and Co., Inc.) DE 1924135, 1969; Chem. Abstr. 1970, 72, 43870n.

(12) Pudovik, A. N.; Gareev, R. D.; Stabrovskaya, L.A. Zh. Obshch. Khim. 1970, 40, 698. Pudovik, A. N.; Gareev, R. D.; Aganov, A.V.; Stabrovskaya, L.A. Zh. Obshch. Khim. 1971, 41, 1241.

Pudovik, A. N.; Gareev, R. D. J. Gen. Chem. USSR (Engl. Transl.) 1975, 45, 19; Zh. Obshch. Khim. 1975, 45, 22-29; Chem. Abstr. 1975, 82, 171149c.

(13) Churi, R. H.; Griffin, C. E. J. Am.Chem. Soc. 1966, 88, 1824-1825.

(14) Sprecher, M.; Kost, D. Tetrahedron Lett. 1969, 9, 703-706.

(15) Ulman, A.; Sprecher, M. J. Org. Chem. 1979, 44, 3703-3707.

(16) Cann, P. F.; Howells, D.; Warren, S. J. Chem. Soc., Perkin Trans. 2 1972, 304- 311.

(17) Griffin, C. E.; Ranieri, R. L. Phosphorus 1976, 6, 161-164. 
(18) Rosowsky, A. in Heterocyclic Compounds with Three and Four Member Rings, Weissberger, A., Ed.; Interscience, New-York, N.Y. 1964, 94-106.

(19) Arbuzov, B. A.; Vinogradova, V. S.; Polezhaeva, N. A. Dokl. Akad. Nauk SSSR 1956, 111, 107-109; Chem. Abstr. 1957, 51, 8001g.

(20) a) Arbuzov, B. A.; Vinogradova, V. S.; Polezhaeva, N. A. Dokl. Akad. Nauk SSSR 1958, 121, 641-643; Chem. Abstr. 1959, 53, 1180i.

b) Arbuzov, B. A.; Vinogradova, V. S.; Polezhaeva, N. A.; Shamsutdinova, A. K. Bull. Acad. Sci. USSR, Div. Chem. Sci. (Engl. Transl.) 1963, 1257; Izv. Akad. Nauk SSSR, Ser. Khim. 1963, 1380-1389; Chem. Abstr. 1963, 59, $15306 f$.

(21) Arbuzov, B. A.; Vinogradova, V. S.; Polezhaeva, N. A. Izv. Akad. Nauk SSSR, Ser. Khim. 1960, 832-841; Chem. Abstr. 1960, 54, 24454 f.

(22) Arbuzov, B. A.; Vinogradova, V. S.; Polezhaeva, N. A. Izv. Akad. Nauk. SSSR, Otdel. Khim. Nauk 1959, 41-49; Chem. Abstr. 1959, 53, 15035e.

(23) Meisters, A.; Swan J. M. Aust. J. Chem. 1965, 18, 168-172.

(24) Sturtz, G. Bull. Soc. Chim. Fr. 1964, 2333-2340.

(25) Abramov,V. S.; Shalman, A. L.; Molodykh, Zh. V. J. Gen. Chem.USSR (Engl. Transl.) 1968, 38, 529-532; Zh. Obshch. Khim. 1968, 38, 541-545; Chem. Abstr. 1968, $69,27487 \mathrm{a}$.

(26) Pudovik, A. N. Zh. Obshch. Khim. 1955, 25, 2173-2182; Chem. Abstr. 1956, 50, $8486 \mathrm{i}$.

(27) Arbuzov, B. A.; Lugovkin, B. P.; Bogonostseva, N. P. Zh. Obshch. Khim. 1950, 20, 1468-1477; Chem. Abstr. 1951, 45, 1506a.

(28) Arbuzov, B. A.; Movsesyan, M. E. Dokl. Akad. Nauk SSSR, Otdel. Khim. Nauk 1959, 267-271; Chem. Abstr. 1959, 53, $19850 f$.

(29) Bogonostseva, N. P. Uch. Zap. Kazan. Gos. Univ. 1956, 116, 71-128; Chem. Abstr. 1957, 51, 6581g.

(30) Herzig, C.; Gasteiger, J. Chem. Ber. 1982, 115, 601-614.

(31) Miller, B. J. Org. Chem. 1961, 26, 4781.

Hoffmann, H. Tetrahedron Lett. 1962, 583.

Miller, B. J. Org. Chem. 1963, 28, 345-348.

Borowitz, I. J.; Virkhaus, R. J. Am. Chem. Soc. 1963, 85, 2183-2184.

(32) Kamai, G.; Kukhtin, V. A. Dokl. Akad. Nauk SSSR 1957, 112, 868; Chem. Abstr.1957, 51, 13742.

Kukhtin, V. A.; Pudovik, A. N. Usp. Khim 1959, 28, 96; Chem. Abstr. 1959, 53, 9025. Tripett, S. J. Chem. Soc. 1962, 2337-2340.

Tripett, S. Proc. Chem. Soc. 1962, 106.

(33) Perkow, W. Chem. Ber. 1954, 87, 755-758. 
Perkow, W.; Krockow, E.W.; Knoevenagel, K. Chem. Ber. 1955, 88, 662-665.

Spencer, E. Y.; Todd, A. R.; Webb, R. F. J. Chem. Soc. 1958, 2968.

Cramer, F. Angew. Chem. 1960, 72, 236-249.

(34) Allen, J. F.; Johnson, O. H. J. Am. Chem. Soc. 1955, 77, 2871-2875.

Kharasch, M. S.; Bengelsdorf, I. S. J. Org. Chem. 1955, 20, 1356-1362.

Chopard, P. A.; Clark, V. M.; Hudson, R. F.; Kirby, A. J. Tetrahedron 1965, 21, 1961-1970.

Sekine, M.; Okimoto, K.; Hata, T. J. Am. Chem. Soc. 1978, 100, 1001-1002.

Sekine, M.; Nakajima, M.; Hata, T. J. Org. Chem. 1981, 46, 4030-4034.

Sekine, M.; Okimoto, K.; Yamada, K.; Hata, T. J. Org. Chem. 1981, 46, 2097-2107.

(35) Malenko, D. M.; Simurova, N. V.; Sinitsa, A. D. J. Gen. Chem. USSR 1993, 63, 657658; Zh. Obshch. Khim. 1993, 63, 943-945.

(36) Russell, G. A.; Ros, F. J. Am. Chem. Soc. 1985, 107, 2506-2511.

Kreutzkampf, N.; Kayser, H.Chem. Ber. 1956, 89, 1614-1619.

(37) Springs, B.; Haake, P. J. Org. Chem. 1976, 41, 1165-1168.

(38) Texier-Boullet, F.; Foucaud, A. Tetrahedron Lett. 1980, 21, 2161-2164.

(39) Hirai, S.; Harvey, R. G.; Jensen, E. V. Tetrahedron 1966, 22, 1625-1640.

(40) Penz, G.; Zbiral, E. Monatsh. Chem. 1982, 113, 1169-1190.

(41) Glebova, Z. I.; Eryuzheva, O. V.; Zhdanov, Yu. A. Russ. J. Gen. Chem. 1993, 63, 1172-1173; Zh. Obshch. Khim. 1993, 63, 1677-1678.

(42) a) Inokawa, S.; Kawata, Y.; Yamamota, K.; Kawamoto, H.; Yamamoto, H., Takagi, K.; Yamashita, M. Carbohydr. Res. 1981, 88, 341-344.

b) Kashino, S.; Inokawa, S.; Haisa, M.; Yasuoka, N.; Kakudo, M. Acta Crystallogr., Sect.B 1981, 37, 1572-1575.

c) Inokawa, S.; Yamamoto, H. Phosphorus Sulfur 1983, 16, 79-81.

(43) Hanaya, T.; Yasuda, K.; Yamamoto, H.;Yamamoto, H. Bull. Chem. Soc. Jpn. 1993, 66, 2315-2322.

(44) Shen, Y.; Liao, Q.; Qiu, W. J. Chem. Soc., Perkin Trans. 1 1990, 695-697.

(45) Kossev, K.; Troev, K.; Roundhill, D. M. Phosphorus Sulfur 1993, 83, 1-7.

(46) Abramov, V. S.; Savintseva, R. N. Khim. Org. Soedin. Fosfora, Akad. Nauk SSSR, Otd. Obshch. Tekh. Khim. 1967, 129-132; Chem. Abstr. 1968, 69, 67465y.

(47) Abramov, V. S.; Kapustina, A. S. Dokl. Akad. Nauk SSSR 1956, 111, 1243-1244; Chem. Abstr. 1957, 51, 9473g.

Abramov, V. S.; Kapustina, A. S. Zh. Obshch. Khim. 1957, 27, 1012-1015; Chem. Abstr. 1958, 52, 3666i.

Kirpichnikov, P. A.; Kapustina, A. S.; Tokareva, G. N. Tr. Kazan. Khim.-Tekhnol. Inst., 1964, 33, 188; Chem. Abstr. 1967, 66, 2619. 
(48) Agawa, T.; Kubo, T.; Ohshiro, Y. Synthesis 1971, 27-28.

(49) Sturtz, G.; Pondaven-Raphalen, A. Phosphorus Sulfur 1984, 20, 35-47.

(50) Giordano, C.; Castaldi, G. J. Org. Chem. 1989, 54, 1470-1473.

(51) Foucaud, A.; Bakouetila, M. Synthesis 1987, 854-856.

Duncan, G. D.; Li, Z.-M.; Khare, A. N.; McKenna, C. E. J. Org. Chem. 1995, 60, 7080-7081.

(52) Levy, J. N.; McKenna, C. E. Phosphorus Sulfur 1993, 85, 1-8.

(53) Benezra, C.; Riess, J.; Ourisson, G. Bull. Soc. Chim. Fr. 1964, 2022.

(54) McEldoon, W. L.; Wiemer, D. F. Tetrahedron 1996, 52, 11695-11704.

(55) Minami, T.; Motoyoshiya, J. Synthesis 1992, 333-349.

(56) a) Griffin, C. E.; Kundu, S. K. J. Org. Chem. 1969, 34, 1532-1539.

b) Sobolev, V. G.; Ionin, B. I. J. Gen. Chem. USSR (Engl. Transl.) 1985, 55, 198; Zh. Obshch. Khim. 1985, 55, 225-226; Chem. Abstr. 1985, 103, 22654p.

c) Hunger, K. Chem. Ber. 1968, 101, 3530-3536.

d) Kadyrov, A. A.; Rokhlin, E. M.; Knunyants, I. L. Bull. Acad. Sci. USSR, Div. Chem. Sci. (Engl. Transl.) 1982, 31, 2063-2066; Izv. Akad. Nauk SSSR, Ser. Khim. 1982 2344-2347.

e) Ryabov, B. V.; Ionin, B. I.; Petrov, A. A. J. Gen. Chem. USSR (Engl.Transl.) 1989, 59, 233-237; Zh. Obshch. Khim. 1989, 59, 272-277.

(57) Sturtz, G.; Pondaven-Raphalen, A. Bull. Soc. Chim. Fr. 1983, 125-130.

(58) Glamkowski, E. J.; Gal, G.; Purick, R.; Davidson, A. J.; Sletzinger, M. J. Org. Chem. 1970, 35, 3510-3512.

(59) Öhler, E.; Zbiral, E.; El-Badawi, M. Tetrahedron Lett. 1983, 24, 5599-5602.

Öhler, E.; Kang, H.-S.; Zbiral, E. Chem. Ber. 1988, 121, 977-990.

Öhler, E.; Zbiral, E. Synthesis 1991, 357-361.

Öhler, E. Monatsh. Chem. 1993, 124, 763-774.

(60) Morel, G.; Seux, R.; Foucaud, A. Bull. Soc. Chim. Fr. 1976, 177-183.

(61) Burgos-Lepley, C. E.; Mizsak, S. A.; Nugent, R. A.; Johnson, R. A. J. Org. Chem. 1993, 58, 4159-4161.

(62) Cristau, H.-J.; Yangkou Mbianda, X.; Geze, A.; Beziat, Y.; Gasc, M.-B. J. Organomet. Chem. 1998, in press.

(63) Horiguchi, M. In Biochemistry of Natural C-P Compounds, Hori, T.; Horiguchi, M.; Hayashi, A., Ed.; Japanese Association for Research on the Biochemistry of C-P Compounds: Tokyo, 1984, pp. 88-103.

Smith, J. D. In The Role of Phosphonates in Living Systems, Hildebrand, R. L., Ed.; CRC Press, Inc. Boca Raton, Florida, 1983, pp. 31-53. 
Hidaka, T.; Mori, M.; Imai, S.; Hara, O.; Nagaoka, K.; Seto, H. J. Antibiotics 1989, 42,491 .

(64) Christensen, B. G.; Leanza, W. J.; Beattie, T. R.; Patchett, A. A.; Arison, B. H.; Ormond, R. E.; Kuehl Jr., F. A.; Albers-Schonberg, G.; Jardetzky, O. Science 1969, $166,123-125$.

(65) Shoji, J.; Kato, T.; Hinoo, H.; Hattori, T.; Hirooka, K.; Matsumoto, K.; Tanimoto, T.; Kondo, E. J. Antibiotics 1986, 39, 1011-1012.

(66) Katayama, N.; Tsubotani, S.; Nozaki, Y.; Harada, S.; Ono, H. J. Antibiotics 1990, 43, 238-246.

(67) Kawakami, Y.; Furuwatari, C.; Akahane, T.; Okimura, Y.; Furihata, K.; Katsuyama, T.; Matsumoto, H. J. Antibiotics 1994, 47, 507-509.

(68) Cassidy, P. J.; Kahan, F. M. Biochemistry 1973, 12, 1364.

Kahan, F. M.; Kahan, J. S.; Cassidy, P. J.; Kroop, H. Ann. N. Y. Acad. Sci. 1974, 235, 364.

(69) Marquardt, J. L.; Brown, E. D.; Lane, W. S.; Haley, T.M.; Ichskawa, Y.; Wong, C.H.; Walsh, C. T. Biochemistry 1994, 33, 10646.

(70) Genua, M. I.; Giraldez, J.; Rocha, E.; Monge, A. J. Pharm. Sci. 1980, 69, 1282- 1284. Ullmann, U.; Lindemann, B. Arzneim. Forsch. 1980, 30, 1247-1249.

Radda, T. M.; Gnad, H. D.; Paroussis, P. Arzneim. Forsch. 1985, 35, 1329-1331.

Fernandez Lastra, C.; Mariño, E. L.; Dominguez-Gil, A. Arzneim. Forsch. 1986, 36, 1518-1520.

Vogt, K.; Rauhut, A.; Trautmann, M.; Hahn, H. Arzneim. Forsch. 1995, 45, 894- 897.

(71) Rogers, T. O.; Birnbaum, J. Antimicrob. Agents Chemother. 1974, 5, 121.

(72) Hammerschmidt, F. Monatsh. Chem. 1991, 122, 389.

Hammerschmidt, F.; Kählig, H. J. Org. Chem. 1991, 56, 2364-2370.

Hammerschmidt, F. Liebigs Ann. Chem. 1991, 469-475.

(73) Hammerschmidt, F. J. Chem. Soc., Perkin Trans. 1 1991, 1993-1996.

(74) Hammerschmidt, F. Liebigs Ann. Chem. 1992, 553.

(75) Inouye, S.; Niizato, T.; Komiya, I.; Yuda, Y.; Yamada, Y. J. Pharm. Dyn. 1982, 5, 941.

(76) Merck Index, 10th ed.; Merck \& Co. Inc.; Rahway, NJ, 1983, p 607.

(77) Scrip. World Pharm. News 1986, 1110, 23. Chiarino, D.; Della Bella, D.; Ferrari, V. Eur. Pat. App. EP 27597, 1982.

(78) Perales, A.; Garcia-Blanco, S. Acta Crystallogr., Sect. B 1978, 34, 238-242.

Perales, A.; Martinez-Ripoll, M.; Fayos, J.; von Carstenn-Lichterfelde, C.; Fernandez, M. Acta Crystallogr., Sect. B 1982, 38, 2763-2764. 
von Carstenn-Lichterfelde, C.; Fernandez-Ibanez, M.; Galvez-Ruano, E.; Bellanato, J. J. Chem. Soc., Perkin Trans. 2 1983, 943-947.

Fernandez-Ibanez, M.; Prieto, A.; Bellanato, E.; Galvez-Ruano, E.; Arias-Perez, M. S. J. Mol. Struct. 1986, 142, 391-396.

(79) Firestone, R. A. Patent (Merck and Co., Inc.) DE 1924098, 1970; Chem. Abstr. 1970, 72, 90629a.

(80) Boisselle, A. P.; Meinhardt, N. A. J. Org. Chem. 1962, 27, 1828-1833.

(81) Girotra, N. N.; Wendler, N. L. Tetrahedron Lett. 1969, 4647-4650.

(82) Firestone, R. A.; Glamkowski, E. J. Patent (Merck and Co., Inc.) DE 1924105, 1970; Chem. Abstr. 1970, 72, 132952h.

Firestone, R. A.; Sletzinger, M. Patent (Merck and Co., Inc.) US 3584014, 1971; Chem. Abstr. 1971, 75, 63977t.

(83) a) Firestone, R. A. Patent (Merck and Co., Inc.) US 3784590, 1974; Chem. Abstr. 1974, 80, 60031.

b) Firestone, R. A. Patent (Merck and Co., Inc.) US 3668197, 1972; Chem. Abstr. 1972, 77, 114560 .

(84) Firestone, R. A. Patent (Merck and Co., Inc.) DE 1924260, 1970; Chem. Abstr. 1970, $72,90622 \mathrm{t}$.

(85) Pollak, P. I.; Christensen, B. G.; Wendler, N. L. Patent (Merck and Co., Inc.) DE 1924169, 1970; Chem. Abstr. 1970, 72, 100882u.

(86) Chemerda, J. M.; Glamkowski, E. J. Patent (Merck and Co., Inc.) DE 1924118, 1970; Chem. Abstr. 1970, 72, 132953j.

Chemerda, J. M.; Glamkowski, E. J. Patent (Merck and Co., Inc.) DE 1924173， 1969; Chem. Abstr. 1970, 72, 43871p.

(87) Chemerda, J. M.; Sletzinger, M. Patent (Merck and Co., Inc.) DE 1924172, 1970; Chem. Abstr. 1970, 72, 90631v.

Pines, S. H.; Karady, S. Patent (Merck and Co., Inc.) DE 1924148, 1970; Chem. Abstr. 1970, 72, 132965q.

Sletzinger, M.; Karady, S. Patent (Merck and Co., Inc.) DE 1924149, 1970; Chem. Abstr. 1970, 72, 90628z.

(88) Christensen, B. G.; Cama, L. D. Patent (Merck and Co., Inc.) DE 2002415, 1970; Chem. Abstr. 1971, 75, 77031s.

Christensen, B. G.; Leanza, W. J. Patent (Merck and Co., Inc.) UK 1244910, 1971; Chem. Abstr. 1971, 75, 129940j.

Pollak, P. I.; Slates, H. L.; Patent (Merck and Co., Inc.) DE 1924251, 1970; Chem. Abstr. 1970, 72, 111614j. 
Glamkowski, E. J.; Rosas, C. B.; Sletzinger, M.; Wantuck, J. A. Patent (Merck and Co., Inc.) FR 2074329, 1971; Chem. Abstr. 1972, 77, 62132.

(89) Schoenewaldt, E. F. Patent (Merck and Co., Inc.) DE 1924231, 1970; Chem. Abstr. 1970, 72, 132972q.

(90) Firestone, R. A. Patent (Merck and Co., Inc.) DE 1924093, 1970; Chem. Abstr. 1970, $72,132971 \mathrm{p}$.

Firestone, R. A. Patent (Merck and Co., Inc.) DE 1924138, 1970; Chem. Abstr. 1970, $72,111613 \mathrm{~h}$.

(91) Shuman, R. F. Patent (Merck and Co., Inc.) DE 1924085, 1970; Chem. Abstr. 1970, 72, 90634y.

(92) Kitamura, M.; Tokunaga, M.; Noyori, R. J. Amer. Chem. Soc. 1995, 117, 2931- 2932.

(93) Bandini, E.; Martilli, G.; Spunta, G.; Panunzio, M. Tetrahedron: Asymmetry 1995, 6, 2127-2130.

(94) White, R. F.; Birnbaum, J.; Meyer, R. T.; Ten Broeke, J.; Chemerda, J. M.; Demain, A. L. Appl. Microbiol. 1971, 22, 55-60.

(95) Machleidt, H.; Strehlke, G. U. Angew. Chem. Int. Ed. Engl. 1964, 3, 443.

Sasse, K. In Methoden der Organischen Chemie, 12, Part I, Müller E., Ed., Georg Thieme verlag, Stuttgart, Germany, 1963, pp 432, 489-495, 523.

Sprecher, M.; Nativ, E. Tetrahedron Lett. 1968, 42, 4405-4408.

(96) Mark, V. Tetrahedron Lett. 1962, 281.

(97) Kost, D.; Sprecher, M. Tetrahedron Lett. 1970, 29, 2535-2536.

(98) Savignac, P.; Leroux, Y. J. Organomet. Chem. 1973, 57, C47-C50.

(99) Sasse, K. In Methoden der Organischen Chemie, 12, Part II, Müller E., Ed., Georg Thieme verlag, Stuttgart, Germany, 1964, p 441.

(100) Redmore, D. Chem. Rev. 1971, 71, 315-337.

(101) Razumov, A. I.; Liorber, B. G.; Moskva, V.V.; Sokolov, M. P. Russian Chem. Rev. 1973, 42, 538-550.

(102) Teulade, M.-P.; Savignac, P. Synth. Commun. 1987, 17, 125-136.

(103) Arbuzov, B. A.; Polezhaeva, N. A.; Vinogradova, V. S. Izv. Akad. Nauk SSSR, Ser.Khim. 1967, 1146-1148; Chem. Abstr. 1968, 68, 13092k.

(104) Ryazantsev, E. N.; Ponomarev, D. A.; Al'bitskaya, V. M. J. Gen. Chem. USSR (Engl.Transl.) 1987, 57, 2056-2059; Zh. Obshch. Khim. 1987, 57, 2300-2303.

(105) Zygmunt, J.; Walkowiak, U.; Mastalerz, P. Pol. J. Chem. 1980, 54, 233-240.

(106) Hammerschmidt, F.; Bovermann, G; Bayer, K. Liebigs Ann. Chem. 1990, 1055- 1061. Hammerschmidt, F.; Kählig, H.; Müller, N. J. Chem. Soc. Perkin Trans. 1 1991, 365369. 
(107) Arca, P.; Rico, M.; Brana, A. F.; Villar, C. J.; Hardisson, C.; Suarez, J. E. Antimicrob. Agents Chemother. 1988, 32, 1552.

Arca, P.; Hardisson, C.; Suarez, J. E. Antimicrob. Agents Chemother. 1990, 34, 844.

Armstrong, R. N. Chem. Res. Toxicol. 1997, 10, 2.

Bernat, B. A.; Laughlin, L. T.; Armstrong, R. N. Biochemistry. 1997, 36, 3050.

(108) Bernat, B. A.; Laughlin, L. T.; Armstrong, R. N. J. Org. Chem. 1998, 63, 3778- 3780.

(109) Baboulene, M.; Sturtz, G. Synthesis 1978, 456-457.

(110) Drescher, M.; Öhler, E.; Zbiral, E. Synthesis 1991, 362-368.

Öhler, E.; El-Badawi, M.; Zbiral, E. Chem. Ber. 1985, 118, 4099-4130.

(111) Eisch, J. J.; Galle, J. E. J. Organomet. Chem. 1976, 121, C10-C14.

Eisch, J. J.; Galle, J. E. J. Organomet. Chem. 1988, 341, 293-313.

(112) Sturtz, G.; Pondaven-Raphalen, A. Tetrahedron Lett. 1978, 629-632.

(113) Christensen, B. G.; Beattie, T. R.; Leanza, W. J. Patent (Merck and Co., Inc.) DE 1805677, 1969; Chem. Abstr. 1969, 72, 67089.

(114) Vidal, 71th ed.; Editions du Vidal, Paris, 1995. 


\section{Biographical Sketches}

(from the left to the right)

Frédéric Eymery was born in 1971 in Chatenay-Malabry (France). Graduating as a technician chemist of the IUT d'Orsay, in 1992, he pursued his studies at the University of Paris XI, where he graduated in organic chemistry (DEA) in 1995. After a stay at GlaxoWellcome, he joined the laboratory of Professor F. Mathey in 1996 as a Ph. D. student at the Ecole Polytechnique (France). His current interests include the synthesis of water soluble phosphines and phosphonates chemistry.

Bogdan Iorga was born in 1975 in Ploiesti, Roumania. He received his B. Sc. in chemistry in 1997 at the University of Bucharest working on the synthesis of carbonic anhydrase inhibitors in the research group of Professor C. T. Supuran. In 1997 he joined the European Program at the Ecole Polytechnique (France) where he is currently working toward his $\mathrm{Ph}$. D. on the electrophilic fluorination and chlorination of phosphonates under the guidance of Dr. P. Savignac.

Philippe Savignac graduated as Ingénieur of the ENSCT in 1963 has received his $\mathrm{Ph}$. D from the Sorbonne (Paris) in 1968. He became an Attaché de Recherche (CNRS) in 1970 in the laboratory of Professor Henri Normant in the Sorbonne and Directeur de Recherche (CNRS) in 1976. In 1977 he joined the research group gathered in Thiais around F. Mathey. Since 1987 he has been working at the Ecole Polytechnique (France). His research interests include organic and organometallic chemistry of phosphorus, synthesis of new phosphorylated reagents, phosphoramidates, phosphonates and $\alpha$-halogenated phosphonates. 